\title{
Taphonomic analysis of saurischian dinosaurs from the Plottier Formation (Upper Cretaceous), Mendoza, Argentina
}

\author{
*Elena Previtera ${ }^{1}$
}

\begin{abstract}
${ }^{I}$ Instituto Argentino de Nivología, Glaciología y Ciencias Ambientales (IANIGLA), CCT-CONICET-Mendoza, Avda. Ruiz Leal s/n Parque Gral. San Martín, C.C. 330, (5500), Mendoza, Argentina.

eprevitera@mendoza-conicet.gob.ar

*Corresponding author: eprevitera@mendoza-conicet.gob.ar
\end{abstract}

\begin{abstract}
The uppermost Cretaceous continental deposits of the Neuquén Basin (west-central Argentina) have yielded a high diversity vertebrate assemblage, including numerous dinosaur species. The Neuquén Group is the richest unit in remains of dinosaur of the basin and comprises the Río Limay, the Río Neuquén and the Río Colorado subgroups. In this group, there is abundance of isolated, disarticulated or partially articulated sauropods and theropods. However, little is known about the taphonomic history of fossil assemblages. In this study, dinosaur remains from the Plottier Formation (late Coniacian-early Santonian) found in the Cerro Guillermo area in southern Mendoza are examined. The investigation of fossil occurrences within the study area revealed the existence of different taphonomic modes, from isolated bones until partially articulated skeletons preserved in deposits of floodplain and fluvial channel settings. SEM-EDS analysis showed the substitution of hydroxyapatite by francolite in the bone microstructure. The presence of fluorine-in one of the cases-suggested a link between the elemental composition and depositional environments: floodplain and fluvial channel. The survey of the vertebrate accumulation types and their sedimentary context allowed documenting a wide range of processes responsible for their genesis, operating within a meandering fluvial environment. This contribution represents a holistic approach about taphonomic history of Cretaceous dinosaurs for assessing the differential preservation of fossil assemblages in fluvial environments.
\end{abstract}

Keywords: Taphonomy, Dinosaurs, Upper Cretaceous, Neuquén Basin, Neuquén Group, Palaeoenvironments, Argentina.

RESUMEN. Análisis tafonómico de dinosaurios saurisquios de la Formación Plottier (Cretácico Superior) de Mendoza, Argentina. Los depósitos continentales del Cretácico Superior de la Cuenca Neuquina (centro-oeste de Argentina) han producido una gran diversidad de vertebrados, incluidas numerosas especies de dinosaurios. El Grupo Neuquén es la unidad de la cuenca más rica en restos de dinosaurios y comprende los subgrupos Río Limay, Río Neuquén y Río Colorado. En este grupo, hay abundancia de saurópodos y terópodos aislados, desarticulados o parcialmente articulados. Sin embargo, se sabe poco sobre la historia tafonómica de los asociaciones fósiles. En este estudio, se examinan restos de dinosaurios de la Formación Plottier (Coniaciano tardío-Santoniano temprano) hallados en el área de cerro Guillermo en el sur de Mendoza. La investigación de las ocurrencias de fósiles dentro del área de estudio reveló la existencia de diferentes modos tafonómicos, desde huesos aislados hasta esqueletos parcialmente articulados preservados en depósitos de llanura de inundación y de canal fluvial. El análisis SEM-EDS mostró la sustitución de hidroxiapatita por francolita en la microestructura ósea. La presencia de flúor-en uno de los casos-sugirió un vínculo entre la composición elemental y los ambientes depositacionales: llanura de inundación y canal fluvial. El estudio de los tipos de acumulación de vertebrados y su contexto sedimentario permitió documentar una amplia gama de procesos responsables de su génesis, operando dentro de un ambiente fluvial meandriforme. Esta contribución representa un enfoque holístico sobre la historia tafonómica de los dinosaurios cretácicos para evaluar la preservación diferencial de las asociaciones fósiles en ambientes fluviales. 


\section{Introduction}

The quality of the fossil record is controlled by different extrinsic and intrinsic factors (physical, chemical and biological) that modify the diversity, abundance and distribution of the preserved fossil assemblages. In this sense, taphonomy is extremely useful for the understanding of the biases that introduce these processes. It thus serves a broader role in incentivizing research over all types of biases that affected, on the one hand, paleontological information during collecting; publication and curation methods and stratigraphic incompleteness on the other (Lyman, 1994; Donovan and Paul, 1998).

Both taphonomy and sedimentology are essential for the reconstruction of the ecological relations among fossil organisms. Only by considering geological-sedimentological and taphonomical data, it is possible to acknowledge the original ecological relationships among fossil organisms (Csiki et al., 2010). Taphonomic research in Mesozoic reptiles is increasing worldwide contributing to clarify palaeoenvironmental, paleontological and biostratigraphic interpretations (e.g., Paik et al., 2001; Britt et al., 2004; Eberth et al., 2006; Britt et al., 2009; Eberth and Currie, 2010; Brown et al., 2013; Casal et al., 2014; Smith et al., 2015; Dai et al., 2015; Canudo et al., 2016, among others).

The remains of cretaceous dinosaurs are plenty and diverse in South America mainly in the Neuquén Basin, located in the northwest Patagonia, Argentina. Most of dinosaur species have been found in Upper Cretaceous strata of the Neuquén Group. This record includes abundant sauropods and theropods of considerable significance from both systematic and phylogenetic viewpoints (e.g., Bonaparte, 1991; Novas, 1996, 1997; Novas and Puerta, 1997; Salgado et al., 1997; Powell, 2003; González Riga, 2003; Wilson, 2002; Calvo and González Riga, 2003; Calvo et al., 2004; Curry Rogers, 2005; Coria and Currie, 2006; Calvo et al., 2007; González Riga et al., 2008, 2009; González Riga and Ortiz David, 2014; Casal et al., 2014; González Riga et al., 2016, among others). Unlike the numerous systematic studies published, sedimentological and taphonomic analyses have been poorly documented (e.g., Garrido et al., 2001; Chiappe et al., 2004; González Riga and Astini, 2007; Previtera, 2011, 2017) and they are lagging behind taxonomic and palaeobiogeographic researches. The paucity of taphonomic studies diminishes not only the option of accurate comparisons among different vertebrate assemblages but their stratigraphic provenance as well. Additionally, it reduces the possibility of studying the disposition in the sedimentary deposit of fossil specimens often unknown or undocumented. However, in Patagonia, a detailed study from a taphonomic point of view was made to the sauropod Aeolosaurus colhuehuapensis Casal et al. (2014).

This work reports a detailed taphonomic analysis about dinosaur-bearing intervals from the Plottier Formation (Neuquén Group) in the Cerro Guillermo area (southern Mendoza, Argentina) that integrates sedimentary facies descriptions with preservation taphonomic modes so as to reconstruct burial environments.

\section{Geological setting}

The Neuquén Basin is considered one of the most important sites in South America on account of its occurrences in terrestrial and marine fossils. This basin is located at the eastern side of the Andes in west-central Argentina between $32^{\circ}$ and $40^{\circ} \mathrm{S}$ latitude (Fig. 1). It spreads between the active magmatic arc along the Andes Range to the west, the Sierra Pintada System to the northeast, and the North Patagonian Massif to the southeast (Legarreta and Gulisano, 1989; Vergani et al., 1995). It covers an area of over $120,000 \mathrm{~km}^{2}$ and comprises a nearly continuous record of up to $6,000 \mathrm{~m}$ of stratigraphic thickness from the late Triassic to early Cenozoic (Schwarz, 2012). This sedimentary record includes continental and marine siliciclastics, carbonates and evaporites accumulated under a variety of basin styles, including syn-rift, post-rift/sag and foreland phases (Legarreta and Uliana, 1991; Howell et al., 2005). At a large scale (100-1000 m), marine and continental deposits alternate, representing transgressive-regressive episodes (Digregorio and Uliana, 1980; Legarreta and Uliana, 1991).

The Neuquén Group (early Cenomanian-middle Campanian) sensu Cohen et al. (2013) (Fig. 2) constitutes a sequence of continental sediments deposited during the initial foreland stage of the Neuquén Basin (Franzese et al., 2003). It is the richest dinosaur-bearing unit of the basin, including sauropods, ornithopods and theropods, as well as other vertebrate groups (Leanza et al., 2004). This group reaches $\sim 1,200 \mathrm{~m}$ of maximum thickness (Cazau 

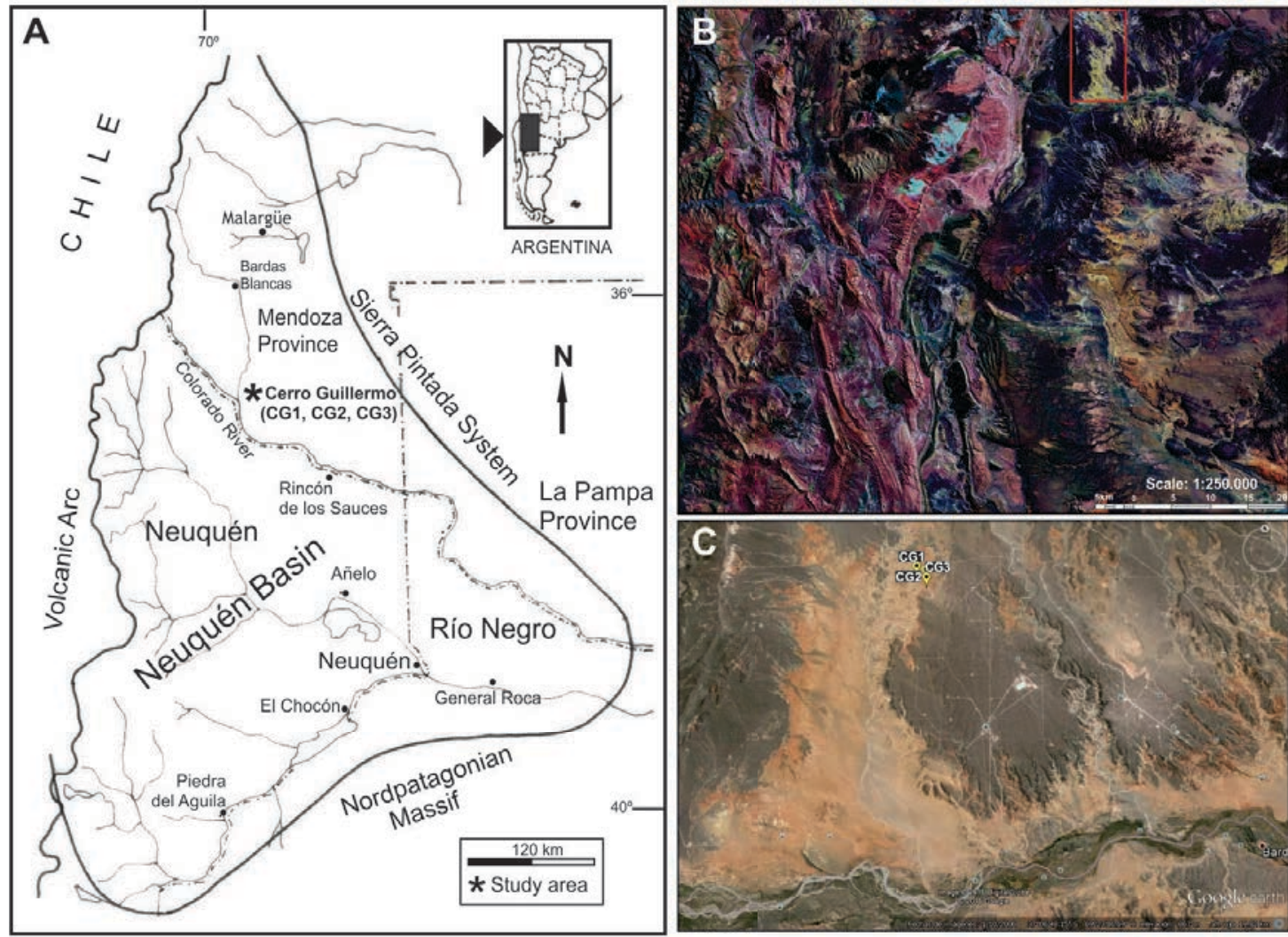

FIG. 1. A. Location map of the Neuquén Basin showing the Cerro Guillermo study area (modified from Previtera, 2017); B. Satellite image of the Chos Malal, 3769 III (data from Groeber, 1946) indicating within a red rectangle the Cretaceous outcrops of the Cerro Guillermo in the southern Mendoza; C. Google Earth image indicating the paleontological sites (CG1, CG2 and CG3).

and Uliana, 1973) being bounded at the base by the Patagonidican unconformity (Keidel, 1917; Leanza, 2009) and at the top by the Huantraiquian unconformity (Méndez et al., 1987) separating it from the Loncoche Formation (late Campanian-early Maastrichtian), the lower unit of Malargüe Group (Andreis et al., 1974; Digregorio and Uliana, 1980; Legarreta et al., 1989). These unconformities have been located at the base of the Cenomanian (Leanza, 2009; Tunik et al., 2010) and in the middle Campanian (Dingus et al., 2009) respectively (Fig. 2). Lithologically, this group comprises a succession of sandstones, conglomerates and claystones which represent alluvial fans; fluvial systems and playa-lake environments stacked in recurrent fining-upward sequences (Leanza and Hugo, 2001). The Neuquén Group is divided-from bottom to top-into the Río Limay (de Ferraríis, 1968), the Río Neuquén (de Ferraríis, 1968; Cazau and Uliana, 1973) and the Río Colorado (Cazau and Uliana, 1973) subgroups (Ramos, 1981). The current lithostratigraphic model of the Neuquén Group proposed by Garrido (2010) regards a subdivision of these subgroups into seven formations according to the following scheme: Río Limay Subgroup (Candeleros and Huincul formations); Río Neuquén Subgroup (Cerro Lisandro, Portezuelo, Los Bastos, Sierra Barrosa and Plottier formations), and Río Colorado Subgroup (Bajo de la Carpa and Anacleto formations).

In southern Mendoza, in the Cerro Guillermo (CG) study area, the most ancient outcropping strata of the Neuquén Group correspond to the Cerro Lisandro Formation (middle-late Turonian), Río Neuquén Subgroup. The Río Neuquén Subgroup (middle Turonian-early Santonian) comprises an interbedded succession of muddy and sandy deposits. It is covered by sandstones, shales and conglomerates of the Río Colorado (Santonian-early Campanian) Subgroup (Garrido, 2010). The Río Neuquén and Río Colorado subgroups include sedimentary sequences composed of alluvial plains and channel complexes 


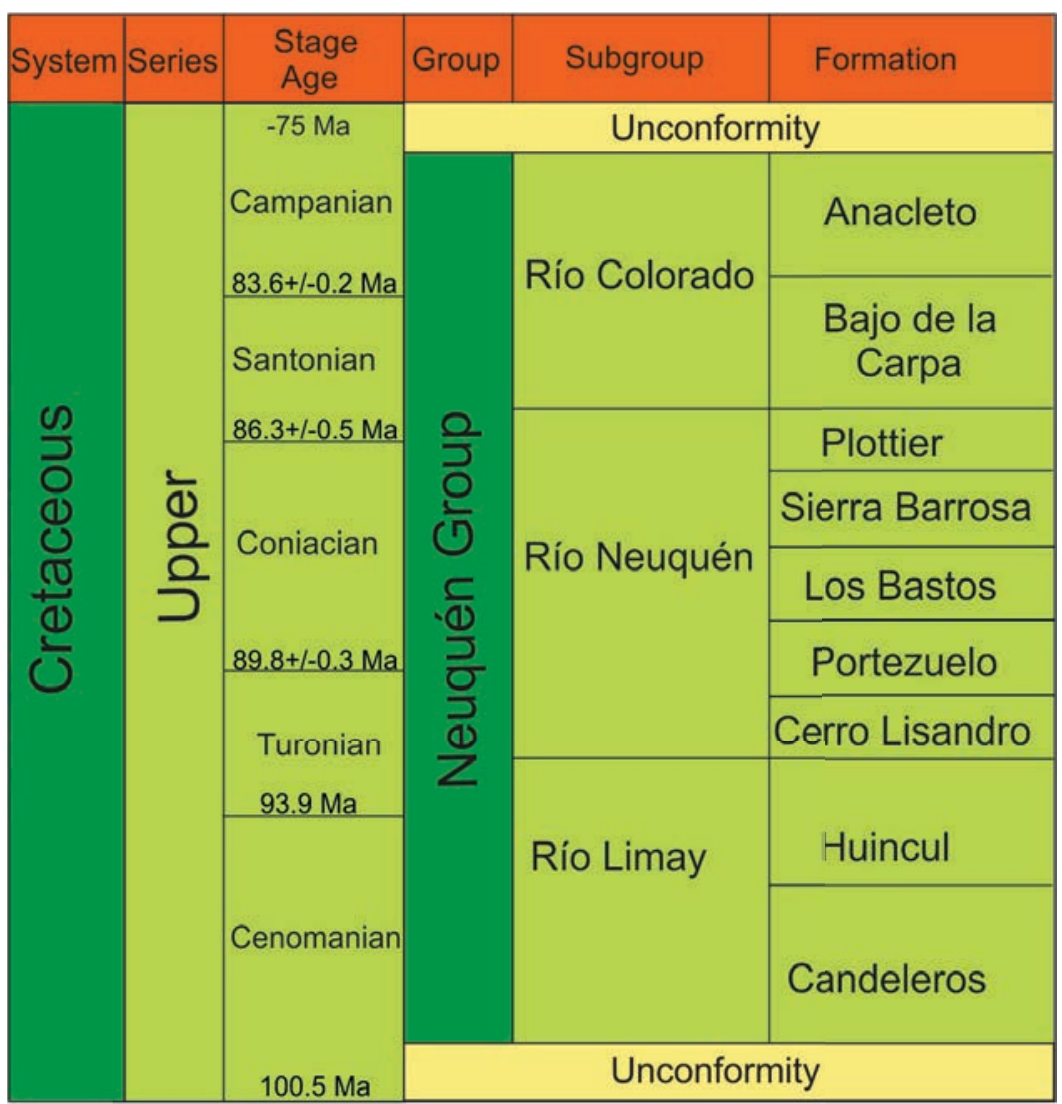

FIG. 2. Lithostratigraphic scheme of the Neuquén Group. Chronostratigraphic scale according to Cohen et al., 2013.

that periodically alternate, forming two distinct facies associations (González Riga and Astini, 2007). According to Previtera (2011), the basal levels of the outcrops here described and that are located northwards and eastwards of the CG were assigned to the Plottier Formation (late Coniacian-early Santonian) (Hugo and Leanza, 2001; Garrido, 2010), Río Neuquén Subgroup. Whereas that the cuspidal levels outcropping in the CG were correlated with the Bajo de la Carpa (Santonian) (Hugo and Leanza, 2001; Garrido, 2010) and Anacleto (early Campanian) (Legarreta and Gulisano, 1989) formations, Río Colorado Subgroup.

\section{Materials and methods}

The materials used for this study comprise an associated partial skeleton of Notocolossus gonzalezparejasi (González Riga et al., 2016) UNCUYOLD.301, and a specimen referred to this UNCUYOLD.302, that includes an associated partial skeleton of a second, smaller-bodied individual. Additionally, here it is described disarticulated but associated indeterminate sauropod bones IANIGLA-PV.113. All the sauropod specimens were collected in the Plottier Formation (Neuquén Group) in three fossiliferous sites of CG area (CG1, CG2 and CG3). Dinosaur specimens were discovered by the Bernardo González Riga in paleontological fieldworks in which the author of this work (E.P.) actively participated. The skeletons of the Notocolossus are housed at the Universidad Nacional de Cuyo, whereas that the indeterminate sauropod bones are housed at the IANIGLA, both repositories located in Mendoza, Argentina.

\subsection{Fieldworks}

Conventional stratigraphic sections were measured and detailed logs were taken after field-based facies analysis. Lateral mapping and photographs indicate the lateral continuity of beds and sedimentary 
architecture. Detailed facies and architectural element analysis was performed following the Miall (1996). For evaluation of taphonomic signature followed the methods defined by Behrensmeyer (1978, 1991); Behrensmeyer and Hook (1992); Alcalá Martínez (1994) and Rogers et al., 2007. These methods included quarry maps generated with a meter grid system and photographs, as well as the description of taphonomic modes and attributes. For the orientation measures of elongate skeletal elements it was employed a Brunton compass. The strike and dip of long axes of appendicular bones (e.g., femur, tibiae and humerus) and anteroposterior axis of articulated vertebrae were plotted in stereoplots.

\subsection{SEM-Energy Dispersive X-ray Spectra (EDS)}

The elemental composition of the carbon-coated bone sample IANIGLA-PV.113-7 was obtained using a scanning electron microscope (SEM) JEOL JSM-6610 LV equipped with an energy dispersive spectrometer (Thermo Scientific Ultra Dry Noran Sysytem 7) in MEBYM, IANIGLA-CONICET. For the EDS maps, it was used an acquisition live time of 30 seconds, the energy of the excitation beam was set equal to $15 \mathrm{keV}, 35.1 \mathrm{deg}$ take off angle and $10 \mathrm{~mm}$ working distance. Results provided by the standard procedure are qualitative. The Proza Phi-Rho-Z algorithmic correction method (Bastin et al., 1986) was used to perform matrix correction. Map-scans were performed from the bone's edge through the cortex towards the medullary cavity. Two categories were used referring to the concentrations of elements present in the sample: major and minor elements. The weight percentage of major components $(\mathrm{C}, \mathrm{O}, \mathrm{F}, \mathrm{P}$, $\mathrm{Ca}, \mathrm{Si}$ ) and minor components (Al, $\mathrm{Mg}, \mathrm{Na}, \mathrm{K}, \mathrm{S}, \mathrm{Cl}$ ) were determined at each point. They were selected in order to differentiate major pore fillers and/or bone substituents (e.g., Si, Mg, Ca, F) of the original bone composition represented by carbonates and phosphates.

Institutional Abbreviations: UNCUYO-LD: Universidad Nacional de Cuyo, Laboratorio de Dinosaurios; IANIGLA-PV: Instituto Argentino de Nivología, Glaciología y Ciencias Ambientales, Mendoza, Argentina, Paleontología de Vertebrados.

\section{Facies associations and paleoenvironments}

Red beds outcropping in the Plottier Formation at the $\mathrm{CG}$ area include three different fossiliferous sites
(CG1, CG2 and CG3, previously shown in figure 1) here analyzed. The architectural arrangement of these units shows the development of the fluvial system (Fig. 3). Sedimentary features of these deposits refer to tractive high energy fluvial facies (channels and bars) interbedded with fine floodplain facies. Based on the codes and definitions summarized by Miall (1996), distinct alternating facies associations are recognized within the succession in CG. These associations represent floodplain environments and sandy fluvial channel complexes (Fig. 3), whose lithofacies and architectural elements are summarized in table 1. Facies associations are described below as (A) floodplain and (B) fluvial channel.

\subsection{Facies association A: Floodplain}

This association includes red massive and mottled mudstones, claystones and siltstones (Fm), rarely laminated (Fl) interbedded with tabular or lenticular sandstones (Sm, Sh, Sr, St, Sp) and paleosol levels (P). Within the massive intervals (Fig. 4A), intense disruptions of original sedimentary structures and fabrics occur by tubular burrowing (possible pedotubules), infiltrated clay partings, and local abundance of irregular, massive clay-rich glaebules and calcareous nodules composed mainly of calcite and quartz (Fig. 4B). Less frequent intervals of $0.5 \mathrm{~m}$ show fine sandstones that locally contain pelitic intraclasts and ripple cross-lamination (Fig. 4C). Horizons with intense greenish grayish mottling and diffuse boundaries are also present. The paleosol levels (P) comprise red, whitish and visibly mottled sandy mudstones with proportions of fine to mediumgrained 5-10\% (Fig. 4D).

Within the dominantly fine-grained sedimentation, tabular, thin-bedded, slightly graded medium-to fine-grained sandstones with various sedimentary structures are present. From bottom to top, individual sandstone beds range 0.03-0.3 $\mathrm{m}$ and show a lower massive $(\mathrm{Sm})$ to laminated interval $(\mathrm{Sh})$, rippled tops with sets of cross-lamination ( $\mathrm{Sr}$ ) bioturbated and conglomeratic. Beds at the top commonly show lenticular geometries and slightly coarser sandstones with trough cross-bedding (St) and planar crossbedding ( $\mathrm{Sp}$ ), as well as lags and intraclasts.

These facies associations contain diverse trace fossil together with vertebrate remains. The ichnological record exhibits typical characteristics of floodplain ichnofaunas such as a low to moderate 

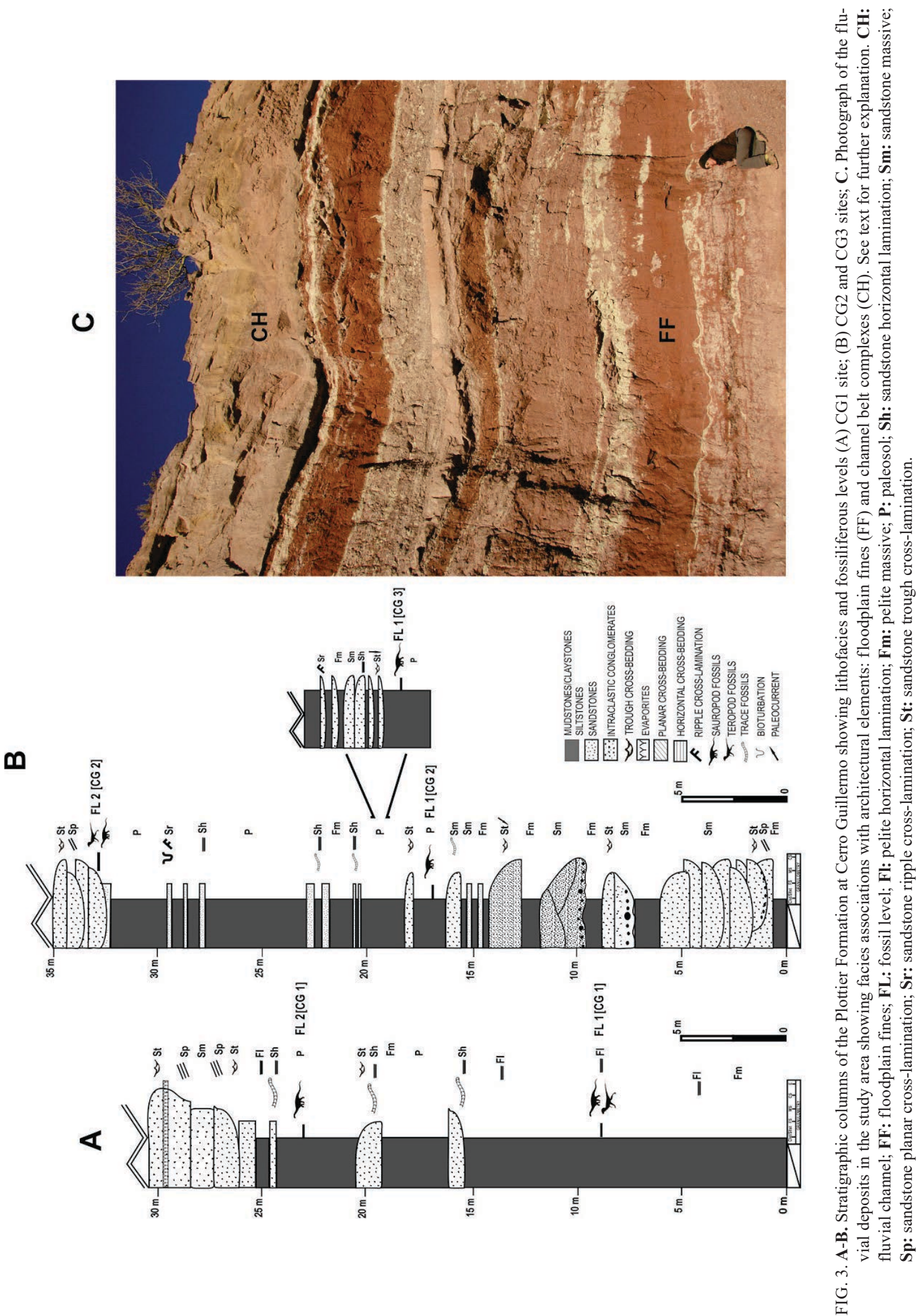
TABLE 1. LITHOFACIES AND ARCHITECTURAL ELEMENTS RECOGNIZED IN THE CERRO GUILLERMO, MENDOZA, ARGENTINA (MODIFIED FROM PREVITERA, 2017).

\begin{tabular}{|c|c|c|c|c|c|c|}
\hline Cody & Lithology & Geometry & $\begin{array}{l}\text { Sedimentary } \\
\text { structures }\end{array}$ & Interpretation & $\begin{array}{l}\text { Architectural } \\
\text { elements }\end{array}$ & $\begin{array}{c}\text { Fluvial sub- } \\
\text { environments }\end{array}$ \\
\hline $\mathrm{Fm}$ & $\begin{array}{l}\text { Claystones } \\
\text { Siltstones }\end{array}$ & Tabular & Massive & $\begin{array}{l}\text { Deposits of decantation, } \\
\text { Overbank deposits }\end{array}$ & $\begin{array}{l}\text { FF (Floodplain } \\
\text { fines) }\end{array}$ & $\begin{array}{l}\text { Floodplain and } \\
\text { floodbasin deposits }\end{array}$ \\
\hline $\mathrm{Fl}$ & Siltstones & Tabular & $\begin{array}{l}\text { Fine horizontal } \\
\text { lamination }\end{array}$ & $\begin{array}{l}\text { Overbank deposits or } \\
\text { flood deposits }\end{array}$ & $\begin{array}{l}\text { FF (Floodplain } \\
\text { fines) }\end{array}$ & $\begin{array}{l}\text { Distal/proximal } \\
\text { deposits }\end{array}$ \\
\hline $\mathrm{P}$ & $\begin{array}{l}\text { Sandy/Mud } \\
\text { carbonates }\end{array}$ & $\begin{array}{l}\text { Fine irregular } \\
\text { horizon }\end{array}$ & $\begin{array}{l}\text { Pedogenic features: } \\
\text { concretions and } \\
\text { calcareous nodules }\end{array}$ & $\begin{array}{l}\text { Soil with chemical } \\
\text { precipitation }\end{array}$ & $\begin{array}{l}\text { FF (Floodplain } \\
\text { fines) }\end{array}$ & Paleosols \\
\hline $\mathrm{Sm}$ & $\begin{array}{l}\text { Fine to coarse- } \\
\text { grained } \\
\text { sandstones }\end{array}$ & $\begin{array}{l}\text { Tabular to } \\
\text { lenticular }\end{array}$ & Massive & $\begin{array}{l}\text { Varied tractive deposits } \\
\text { intense biological } \\
\text { activity }\end{array}$ & $\begin{array}{l}\text { CR (Crevasse } \\
\text { channel) } \\
\mathrm{CH}(\text { Channel) }\end{array}$ & $\begin{array}{l}\text { Overflow deposits } \\
\text { Sandy fluvial channels }\end{array}$ \\
\hline $\mathrm{Sh}$ & $\begin{array}{l}\text { Fine to medium- } \\
\text { sandstones }\end{array}$ & Tabular & $\begin{array}{l}\text { Horizontal } \\
\text { Lamination }\end{array}$ & $\begin{array}{l}\text { Plane-bed deposits } \\
\text { (critical flow) }\end{array}$ & $\begin{array}{l}\text { CS (Crevasse } \\
\text { splay) }\end{array}$ & Overflow deposits \\
\hline St & $\begin{array}{l}\text { Fine to coarse- } \\
\text { grained } \\
\text { sandstones }\end{array}$ & Lenticular & $\begin{array}{l}\text { Trough cross } \\
\text { stratification }\end{array}$ & $\begin{array}{l}3 \mathrm{D} \text { bedforms (lower } \\
\text { flow regimen) }\end{array}$ & $\begin{array}{l}\text { CS/CR (Crevasse) } \\
\mathrm{CH} \text { (Channel) }\end{array}$ & $\begin{array}{l}\text { Overflow deposits } \\
\text { Channel belt } \\
\text { complexes }\end{array}$ \\
\hline $\mathrm{Sr}$ & $\begin{array}{l}\text { Fine to medium- } \\
\text { grained } \\
\text { sandstones }\end{array}$ & Tabular & $\begin{array}{l}\text { Ripple cross } \\
\text { lamination }\end{array}$ & $\begin{array}{l}\text { Ripple (lower flow } \\
\text { regime) }\end{array}$ & $\begin{array}{l}\text { CS (Crevasse } \\
\text { splay) }\end{array}$ & $\begin{array}{l}\text { Sheet-flood, distal } \\
\text { crevasse splay deposits }\end{array}$ \\
\hline $\mathrm{Sp}$ & $\begin{array}{l}\text { Fine to coarse- } \\
\text { grained } \\
\text { sandstones }\end{array}$ & $\begin{array}{l}\text { Tabular to } \\
\text { lenticular }\end{array}$ & $\begin{array}{l}\text { Planar cross } \\
\text { lamination }\end{array}$ & $\begin{array}{l}\text { 2D bedforms (lower } \\
\text { flow regime) }\end{array}$ & $\begin{array}{l}\mathrm{CS} / \mathrm{CR} \text { (Crevasse) } \\
\mathrm{CH} \text { (Channel) }\end{array}$ & $\begin{array}{l}\text { Overflow deposits } \\
\text { Fluvial channel } \\
\text { complexes }\end{array}$ \\
\hline
\end{tabular}
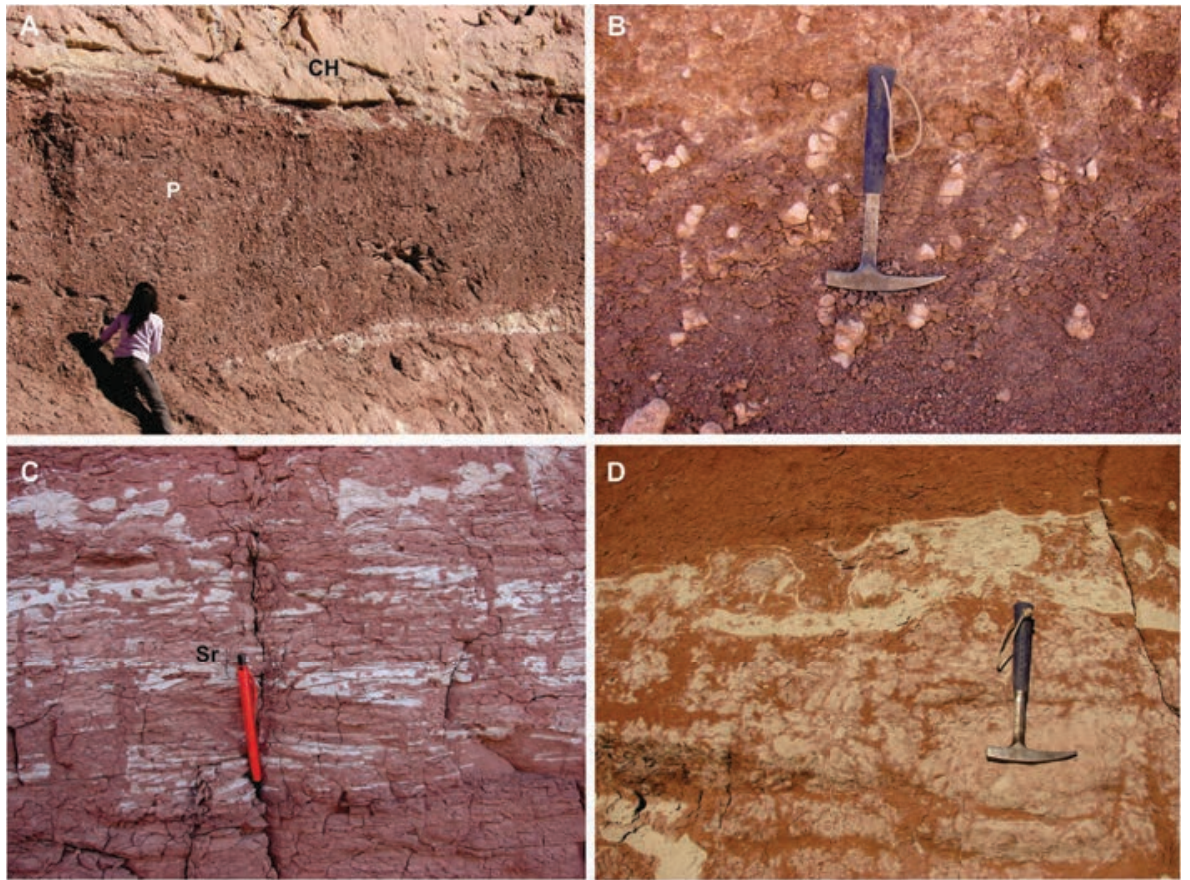

FIG. 4. Detailed photographs of the floodplain facies from the Cerro Guillermo area. A. Paleosol horizons underlying the channel belt; B. Detail of the paleosol level showing abundant calcareous nodules; C. Fine sandstones containing pelitic intraclasts and ripple cross-lamination; D. Red sandy mudstones with whitish mottled. CH: fluvial channel; P: paleosol; Sr: sandstone ripple cross-lamination. 
diversity and dominance of locomotion and feeding structures generated by detritivorous organisms (Ekdale et al., 1984; Frey et al., 1984) or mainly produced by arthropods in ephemeral lakes and floodplains (Bridge, 2006). Although this record is relatively scarce, its good preservation allow recognize the representative features of the Scoyenia ichnofacies (Buatois and Mangano, 1996) with low ichnodiversity and dominance of meniscate structures associated with stress conditions. Vertebrates include mainly remains of sauropods which are thoroughly analyzed in the taphonomy section.

The floodplain facies association is comparable to Miall's $(1985,1996) \mathrm{FF}$ architectural element and is interpreted as a product of accumulation (verticalaccretion deposits) of fines in variously drained, low-gradient floodplains. These deposits were formed from subaqueous sedimentation dominant processes associated with shallow lacustrine bodies. However, part of this association could also have eolian origin "paleoloess". Overall, thin-bedded tabular sandstones are interpreted as crevasse splay deposits caused by episodes of deposition when waning floods overtop the river banks (Miall, 1996; Bridge, 2003; Fisher et al., 2007). These sandy facies reflect the origin of overflows caused by episodic flooding and flood irregular sheets (Miall, 1996) fed from the crevasse channel (CR).

The dominantly massive and mottled structure of mudstones is the result of early diagenetic modification and soil-forming processes. Physical and biological modification in floodplain deposits commonly results after periods of subaerial exposure. Exposure renders near-surface sediments susceptible to soilforming processes that eliminate primary structures (Retallack, 2001). Disruptions of original sedimentary structures and fabrics by burrowing organisms, infiltrated textures -a product of illuviation- and local abundances of glaebules and rhizoliths suggest paleosols development.

The presence of trace fossils like Scoyenia implies environments subject to periodic flooding and drying (Frey et al., 1984; Buatois and Mangano, 1995, 1996). However, the absence of sedimentary structures in the majority of the pelitic facies, together with the record of dinosaurs; concretions; calcareous nodules, and traces of invertebrates evidence a significant biological activity in the floodplains subject to intense bioturbation and development of surrounding vegetation.

\subsection{Facies association B: Fluvial channel}

A variety of distinct, large-scale bodies (1-5 m) of coarse sandstones ranging in size from lens to sheet-like geometries, predominantly fine-grained succession at a broader scale. Such packages conform a higher hierarchy elements that are limited by significant stratigraphically surfaces (third order, sensu Miall, 1996). These sandstone bodies frequently show internal amalgamation and yield lateral continuity of several kilometers (Fig. 5A). The individual channels have an irregular base and a series of structures reflecting a gradual decrease in the flow regime. Progressively thinner trough and planar cross-bedded sets (mesoscale St and Sp) are recorded near the top of individual sandstone bodies, which end up at the top with fining-upward arrangements. Within this association, it is frequently observed lateral accretion surfaces (Fig. 5B). Between each deposit of individual sandy channels, there are fine facies deposits reflecting episodes of decantation (Fig. 5C). This facies is composed of coarse-grained sandstones with abundant pelitic intraclasts that can reach $1 \mathrm{~m}$ in diameter (Fig. 5D) arranged in banks of up to $2 \mathrm{~m}$ thick and lenticular geometry. Also, this association contains isolated bones of indeterminate sauropod and theropod dinosaurs transported as basal lag deposits.

The variety of large-scale isolated or amalgamated sandstone packages are interpreted as main fluvial channels or channel belt complexes ( $\mathrm{CH}$ elements according to Miall, 1996). The internal arrangements, particularly the degree of amalgamation, discriminate multi-story and single-story end members. Two distinct channel sets the predominantly fine-grained succession of the Río Colorado subgroup. Amalgamation patterns in the multi-story, multilateral sandstones indicate stratigraphic condensation. Multi-story or complex fills are mostly interpreted as mobile, broad, shallow channels that generate largely sheet-like geometries (Friend et al., 1979; Bridge, 1993).

In contrast, single-story bodies show a finingupward trend that indicates greater stratigraphic completeness related to available accommodation. Fining-upward trends indicate progressive abandonment or lateral migration. Meter-scale, gently inclined surfaces observed within $\mathrm{CH}$ sandstone bodies and oblique to perpendicularly oriented paleoflows are interpreted as lateral accretion surfaces deposited by high sinuosity rivers through low-gradient plains. 

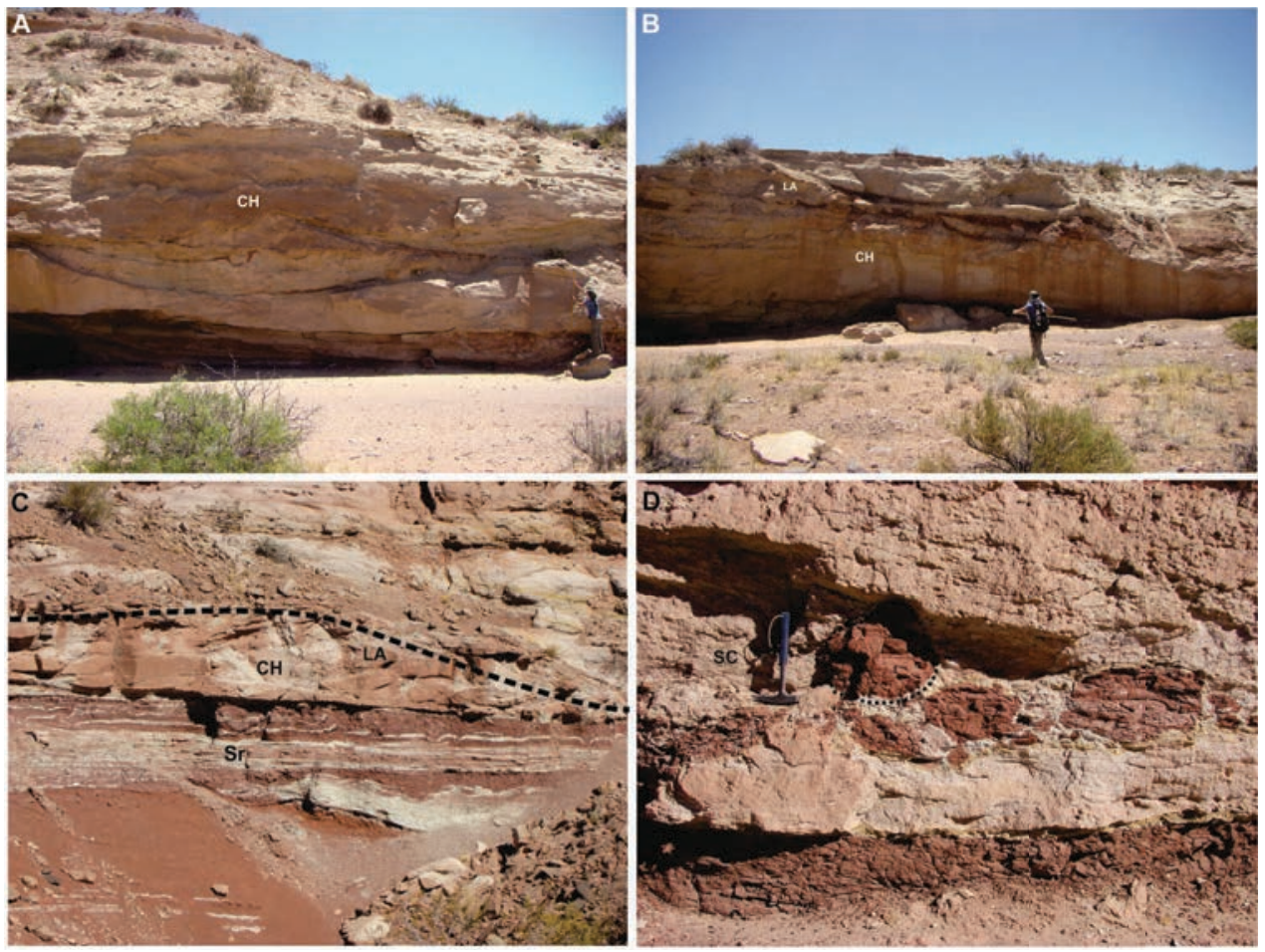

FIG. 5. Detailed photographs of the fluvial channel facies from the Cerro Guillermo area. A. Multi-story amalgamated fluvial channels; B. Channel belt complexes with lateral continuity; C. Detail of fluvial channel showing lateral accretion surfaces interbedded with sandstones ripple cross-lamination; D. Coarse-grained sandstones with abundant pelitic intraclasts. CH: fluvial channel; LA: lateral accretion; SC: coarse-grained sandstone; Sr: sandstone ripple cross-lamination.

\subsection{Palaeoenvironmental setting}

The facies of the Río Neuquén Subgroup include a variable suite of alluvial plain facies and channel complexes that periodically alternate, forming the two distinct facies associations. Low-gradient fluvial plains with developed mixed-load meander belts within extensive floodplains are consistent with slow subsidence in the external position of the Neuquén Basin (González Riga and Astini, 2007). However, drainage from the east-southeast to west-northwest and sandstone composition (Vergani et al., 1995; González Riga, 2002; Previtera, 2011) indicates that sources were localized toward a cyclically active forebulge where basement rocks with an important Triassic volcano-sedimentary cover were intermittently exposed. At a larger scale within the Río Neuquén Subgroup, the alternating and contrasted stacking pattern of sheet-like fluvial belts and alluvial plain intervals, dominated by fine accumulation and isolated channels, indicates variations in the accommodation/ sediment supply rates (González Riga and Astini, 2007). This recurrent pattern probably relates to tectonic activity that periodically contributed to readjust the longitudinal gradient and the stratigraphic base level in the basin (e.g., Plint and Browne, 1994; Martinsen et al., 1999).

At the base of the Cerro Guillermo (CG1, CG2 and CG3 sites) outcrops show a low relation of channel/ floodplain with a strong aggradation of pelitic deposits in the floodplain, where the proportions of fines are high relative to the proportions of sand. This shows a rate of return of the channels relatively low, with a predominance of floodplain deposits compatible with good accommodation space (Previtera, 2011). This fact suggests the development of isolated lenticular channels in floodplain deposits and levees, crevasse splays and sheet floods events (Sánchez et al., 2006). The restriction of the channel systems can be related to the climatic conditions probably combined with subsidence that have temporarily controlled the development of the system. 
Subsequently, water supply conditions and a more stable sediment allowed the development of more extensive and powerful channels, enabling the gradual passage in the upper sectors toward a fluvial moderate/high sinuosity meandering type. Gradually, an increasing on the channel/floodplain relation is recorder. This pattern accompanied by the location of the channels in the most stable alluvial-belt. This situation favored the development of avulsion episodes associated with crevasse channels (Previtera, 2011).

According to Sánchez et al. (2006), the evolution of fluvial system in the Plottier Formation shows a large scale geometry of styles I and II. Style I characterized by an ephemeral fluvial system, and the style II with the development of fluvial pattern braided, which are pointing out a progressive decrease on the accommodation/supply. Weather probably varied from sub-humid or sumi-arid to humid climatic conditions with strong seasonal variations. These provoked important changes on the water and sediment discharge onto the fluvial system. In opossite to Sánchez et al. (2006), Garrido (2010) proposes for the Plottier Formation, the development of mixed-load fluvial systems constituted by distal floodplains rich in paleosols associated with small ephemeral canals, until to areas with large isolated paleochannels, simple of mixed charge "ribbon bodies" (Friend, 1983). The recurrent presence of lateral accretion macroforms in these channels indicates the predominant development of high sinuosity fluvial systems (Miall, 1996), criteria adopted in this work. The dinosaur remains here studied were preserved mostly in the floodplain deposits subject to intense pedogenic activity, whereas that a less proportion was registered in the fluvial channels.

The facies associations described in this work have many similarities with the stratigraphic arrangement of facies associations (floodplain and fluvial channel) described by González Riga and Astini (2007), in the paleontological site of Mendozasaurus neguyelap, at the Arroyo Seco locality (Sierra Barrosa Formation) in southern Mendoza (González Riga et al., 2018). The latter is possible due to the close spatio-temporal proximity of the paleontological sites.

\section{SEM-EDS analysis}

Images and maps were performed in the thinsection of the femoral fragment IANIGLA-PV.113 to monitor trends in elemental distributions (Fig. 6).
The EDS recognized the following elements: $\mathrm{C}, \mathrm{O}, \mathrm{F}$, $\mathrm{P}, \mathrm{Ca}, \mathrm{Si}, \mathrm{Al}, \mathrm{Mg}, \mathrm{Na}, \mathrm{K}, \mathrm{S}, \mathrm{Cl}$, which were mapped to show their qualitative distribution patterns. The major elements include $\mathrm{C}, \mathrm{O}, \mathrm{F}, \mathrm{P}, \mathrm{Ca}, \mathrm{Si}$, whereas the minor are $\mathrm{Al}, \mathrm{Mg}, \mathrm{Na}, \mathrm{K}, \mathrm{S}, \mathrm{Cl}$. Two areas (cortical bone/medullary cavity) were illustrated with the combination of the informative elements ( $\mathrm{P}, \mathrm{Ca}, \mathrm{F}, \mathrm{Mg}$ ) to recognize the original bone composition and the interaction of fillers and/or substituents components. It is possible to note some differences between cortex and medullary zone in the SEM image and EDS maps. $\mathrm{P}$ and $\mathrm{Ca}$ show a similar concentration in both areas, although in the medullary zone present a highest concentration and more homogeneous distribution. The Ca conforms the bone original composition as well as the diagenetic mineral infilling the pore spaces. The high concentration of $F$ is evident in all the sample. This confirms an ionic substitution of the hydroxyapatite by francolite (carbonatefluorapatite) in the bone microstructure. Finally, the $\mathrm{Si}$ that represents a sedimentary component, is more concentrated in the transition of the cortical bone and the host rock. However, the presence of $\mathrm{Si}$ in the bone matrix is mainly located in the infilling points. In general, the $\mathrm{Al}$ shows a similar distribution to the Si that supports the sandy mudstone rock matrix.

\section{Vertebrate taphonomy}

\subsection{Taphonomic site 1}

In sedimentary units from the Plottier Formation in the CG1 site (see Fig. 3, FL 2), disarticulated but associated bones corresponding to a sauropod indet. IANIGLA-PV.113 were found (Table 2). The bones were recovered from a single horizon and there were no duplicated elements. Skeletal elements included the proximal end of humerus, the distal end of femur, one scapula, one fibula, two incomplete appendicular bones, two dorsal ribs, one coracoid, and one neural arch.

The skeletal elements showed a general SW to $\mathrm{NW}$ trend $\left(185^{\circ}-340^{\circ}\right)$. The long bones (e.g., femur, humerus and fibula) do not showed preferential orientation patterns according to the morphology since they were arranged in both directions (Fig. 7A). However, some bones (e.g., scapula, neural arch and dorsal ribs) displayed a clear SW trend.

The bones exhibited inclinations ranging between $9^{\circ}$ and $42^{\circ}$ in relation to the horizontal stratigraphic plane. This inclination is interpreted as a product of 

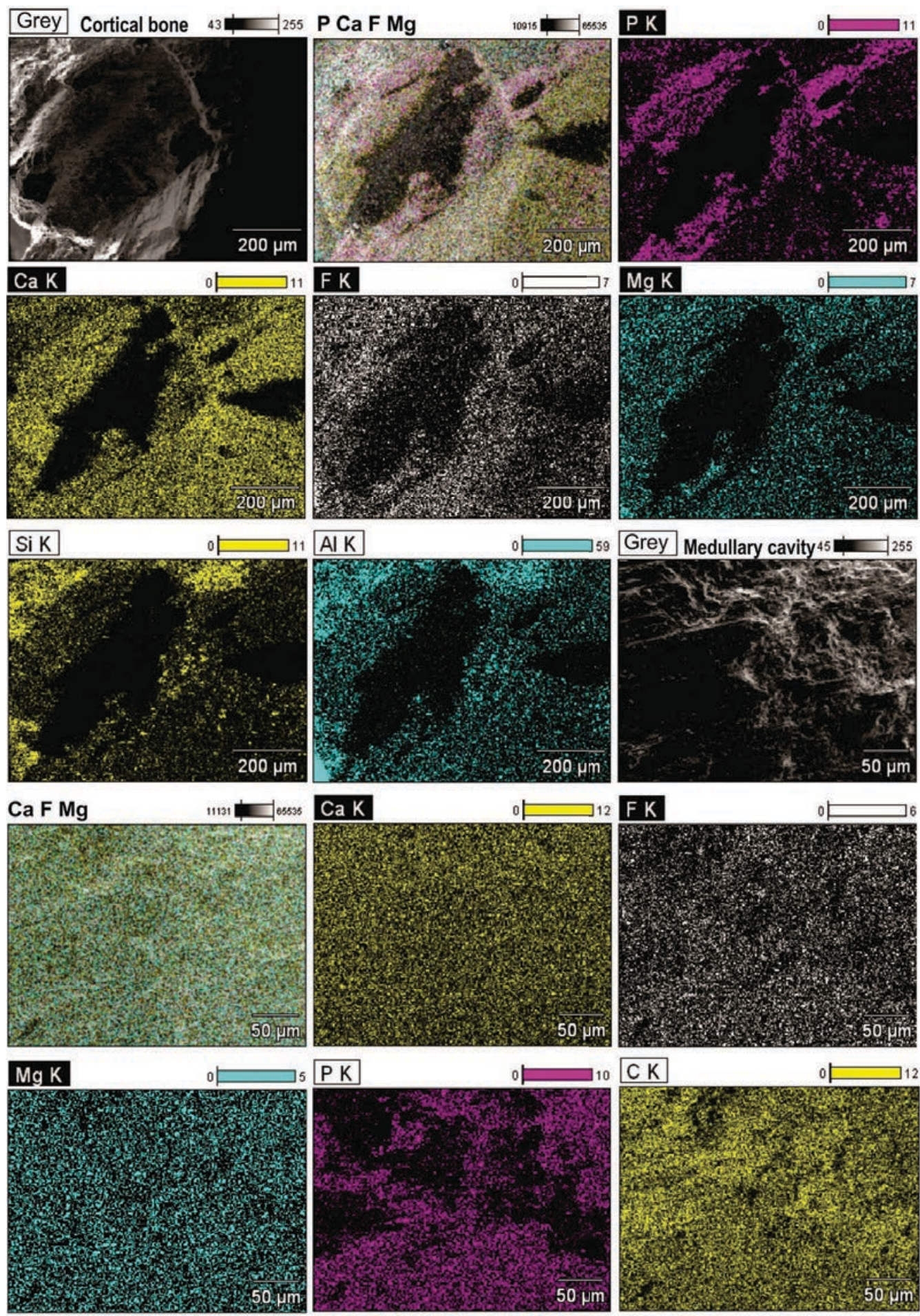

FIG. 6. SEM images and EDS maps of the femoral fragment IANIGLA-PV.113 in a thin-section. Grey photos are the SEM image in different points of the sample. The multicolour images are the superimposition of the grey with the $\mathrm{P}, \mathrm{Ca}, \mathrm{F}$ and $\mathrm{Mg}$ mapping. The colour differences in the maps show the distribution of the different elements in the analyzed points. See text for further explanation. AlK: aluminum; CK: carbon; CaK: calcium; FK: Fluorine; MgK: magnesium; PK: phosphorus; SiK: silica. 
TABLE 2. SUMMARY OF THE MAIN TAPHONOMIC FEATURES OF THE CERRO GUILLERMO DINOSAURS.

\begin{tabular}{|c|c|c|c|c|}
\hline Sites & Taxonomic composition & Description & Taphonomic features & Taphonomic modes \\
\hline CG1 & $\begin{array}{l}\text { Sauropoda indet. } \\
\text { IANIGLA-PV.113 }\end{array}$ & $\begin{array}{l}\text { Incomplete skeleton } \\
\text { composed of associated bones } \\
\text { corresponding to the single } \\
\text { taxon. }\end{array}$ & $\begin{array}{l}\text { Complete disarticulation, } \\
\text { sorting, distortion, } \\
\text { weathering, abrasion high, } \\
\text { absence of crusting. }\end{array}$ & $\begin{array}{l}\text { Disarticulated-associated } \\
\text { bones } \\
\text { Preserved in well-drained } \\
\text { floodplains deposits. }\end{array}$ \\
\hline \multirow[t]{2}{*}{$\mathrm{CG} 2$} & $\begin{array}{l}\text { Notocolossus } \\
\text { Gonzalezparejasi } \\
\text { UNCUYO-LD. } 301\end{array}$ & $\begin{array}{l}\text { Co-occurrence of two or } \\
\text { more skeletal elements } \\
\text { belonging to the same } \\
\text { individual, in various } \\
\text { degrees of completeness } \\
\text { and articulation. }\end{array}$ & $\begin{array}{l}\text { Partial articulation, } \\
\text { weathering, abrasion and } \\
\text { breakage low to moderate } \\
\text { presence of bioerosion and } \\
\text { crusting, absence of } \\
\text { sorting. }\end{array}$ & $\begin{array}{l}\text { Associated specimen } \\
\text { Partial skeleton } \\
\text { Preserved in well-drained } \\
\text { floodplain deposits. }\end{array}$ \\
\hline & $\begin{array}{l}\text { Accumulation of } \\
\text { saurischian remains }\end{array}$ & $\begin{array}{l}\text { Accumulation of small-sized } \\
\text { skeletal elements. More than } \\
\text { one taxon, high diversity. }\end{array}$ & $\begin{array}{l}\text { Complete disarticulation } \\
\text { sorting, weathering } \\
\text { abrasion and breakage } \\
\text { moderate to high. }\end{array}$ & $\begin{array}{l}\text { Isolated bones } \\
\text { Preserved in channel } \\
\text { deposits. }\end{array}$ \\
\hline CG3 & $\begin{array}{l}\text { Notocolossus } \\
\text { Gonzalezparejasi } \\
\text { UNCUYO-LD. } 302\end{array}$ & $\begin{array}{l}\text { Co-occurrence of two or } \\
\text { more bones belonging to } \\
\text { the same specimen in } \\
\text { variable degree of } \\
\text { articulation. }\end{array}$ & $\begin{array}{l}\text { Partial articulation, low weathering, } \\
\text { absence of abrasion, presence of } \\
\text { crusting and distortion, } \\
\text { absence of sorting and } \\
\text { bioerosion. }\end{array}$ & $\begin{array}{l}\text { Associated specimen } \\
\text { Partial skeleton } \\
\text { Preserved in well-drained } \\
\text { floodplain deposits. }\end{array}$ \\
\hline
\end{tabular}

soil compaction by lithostatic load. This phenomenon is common in environments characterized by pelitic deposits susceptible to physical processes of compaction and compression. This is consistent with the degree of distortion or plastic deformation evinced by fossils. The paleoenvironmental context suggests that the bones were oriented horizontally or sub horizontally by shallow and sporadic currents.

In the CG1 site the fossils are mainly large elongated bones (scapula, femur, humerus) together to medians (fibula) and small (dorsal ribs). However, their incompleteness condition determined that they behaved like elements of similar sizes, being able to be selected and transported together by hydraulic currents that occurred during flood. The absence of cranial elements, teeth and phalanges suggests some hydraulic sorting processes. Hence, the smaller and lighter parts could be transported away from the site of accumulation of the remains (Behrensmeyer, 1991).

Moderate cracking of the periosteum is observed in the preserved elements. Long bones have longitudinal fractures parallel to the bone fibers which is associated with the subaerial exposure experienced before the burial -biostratinomic stages- (Fig. 8A). These cracks were subsequently filled by minerals during permineralization events occurring within the sediment -diagenetic stages- as described by the author (see Previtera, 2017). Appendicular bones, dorsal ribs and the scapula show transverse and oblique fractures with smooth edges (Fig. 8B-F). These fractures are typical of dry or slightly weathered bones (Marshall, 1989).

The bones show (1-3) weathering degrees according to Behrensmeyer (1978). The following skeletal elements: scapula, humerus, fibula, femur and appendicular bones exhibit (1,2 stages of weathering) "slightly weathered" with loss of compact tissue; while the dorsal ribs, the coracoid and the neural arch show (3 stage of weathering) "weathered" with loss of spongy tissue and exfoliation their ends. In some long bones absence of epiphysis is observed (Smith, 1993).

In the neural arch, appendicular bones and dorsal ribs, moderate abrasion exhibiting smoothly rounded ends is recognized (category 2 of Alcalá Martínez, 1994). This wearing is associated with a certain degree of sorting by hydraulic transport. In contrast to the remains from CG2 and CG3 sites, the bones of CG1 do not have calcareous crusting in their outer surface. 
Signs of bioerosion associated with plant root activity are recognized in the scapula and long bones. Sinuous roots are also observed with polished and filled by "U"-shaped cross-sections sediments (Andrews, 1990). In most elements, root marks are present on the fracture surface; this indicates that the bone was fractured prior to etching and perhaps prior to burial (White et al., 1998).

In addition, the presence of tubular fossil traces developed on the external surface of appendicular bones and the scapula is recorded (Fig. 8B, D, F). These tubes generated by detritivores organisms, with a diameter of $\sim 0.5 \mathrm{~mm}$, are curved and filled by sandy mudstones. These horizontal structures type Taenidium sp. (Heer, 1877) are burrows filled with well-defined meniscus, typical of environments exposed to floods and episodic desiccations (González Riga et al., 2009). Similar bioerosion features have been reported in a sternal plate of Titanosauridae from Arroyo Seco site (González Riga, 2002).

\subsection{Taphonomic site 2}

In outcrops from the Plottier Formation exposed in the CG2 site (see Fig. 3, FL 1), it was found an associated partial skeleton of a very large individual denominated Notocolossus gonzalezparejasi (González Riga et al., 2016) UNCUYO-LD. 301 (Table 2). The skeleton consists of the right humerus, the proximal end of the left pubis, one anterior dorsal vertebra, and one anterior caudal vertebra. The bones were found within an area of $8 \mathrm{~m}$ by $8 \mathrm{~m}$ at the same stratigraphic level. These elements represent a single titanosaurian individual because they are of the appropriate size and morphology of a single skeleton (González Riga et al., 2016) (Fig. 7B).

The bones showed three different orientations. The right humerus was oriented to southwest, the vertebrae (anterior dorsal and anterior caudal) to the northwest and the proximal end of the left pubis has southeast direction. The values showed a generalized dispersion. The absence of bone sorting by shape and size as well as of preferential orientations indicate non-intense hydraulic processes and of short-term. Therefore, the dispersion of the remains can be attributed to the intervention of biological agents during the bioestratinomic stage. However, to achieve a greater certainty about of the phenomenon that caused the scattering of the bone remains, a highest relative abundance is required.
The humerus and dorsal vertebra (Fig. 8G-K) show slight cracking of the periosteum. The humerus exhibits bioerosion attributes (Fig. 8I, J) related to the activity of roots as well as described in CG1. In the humerus (Fig. 8G-J) it can be recognize two types of fractures: (1) cemented longitudinal fractures parallel to the bone fibers (pre-burial weathering); (2) non-cemented transverse fractures (post-burial or exhumation), both with smooth edges and orthogonal designs "cracked".

Some bones present borings which can be attributed to the action of scavengers or carnivores, that could be linked to the disarticulation and dispersion mentioned above, although this assertion needs further analysis. The fossils are covered by an outer calcareous crust, which could have inhibited the influence of alterative agents (e.g., abrasion).

\subsection{Taphonomic site 3}

In the outcrops from the Plottier Formation in the CG3 site (see Fig. 3, FL 1), it was found an associated partial skeleton of a second, smaller-bodied individual UNCUYO-LD.302 (Table 2) also referred to as Notocolossus gonzalezparejasi (González Riga et al., 2016). The bones include an articulated anterior caudal series (consisting of seven partial vertebrae and haemal arches), the complete and articulated right astragalus and pes and appendicular bones. As in the holotype mentioned above, these elements are considered to represent a single titanosaurian individual because they were found within an area of $5 \mathrm{~m}$ by $5 \mathrm{~m}$ at the same stratigraphic level. They are of the appropriate size and morphology to belong to a single skeleton (González Riga et al., 2016) (Fig. 7C).

The anterior caudal section (Fig. 8L) exhibits slight weathering stage 1 of Behrensmeyer (1978) in relation to the articulated foot (Fig. 8M, N), that shows no evidence of weathering and is attributed to the stage 0 of intact bone. This situation is due to the foot bones were extracted at greater depth $(\sim 2 \mathrm{~m})$ below ground level, therefore, they are less weathered with respect to the other bones exposed in the surface. The skeletal elements show no evidence of abrasion attributed the category 1 of Alcalá Martínez (1994).

All the bones analyzed are covered by a calcareous crust. Some of them, as the foot, have carbonate 


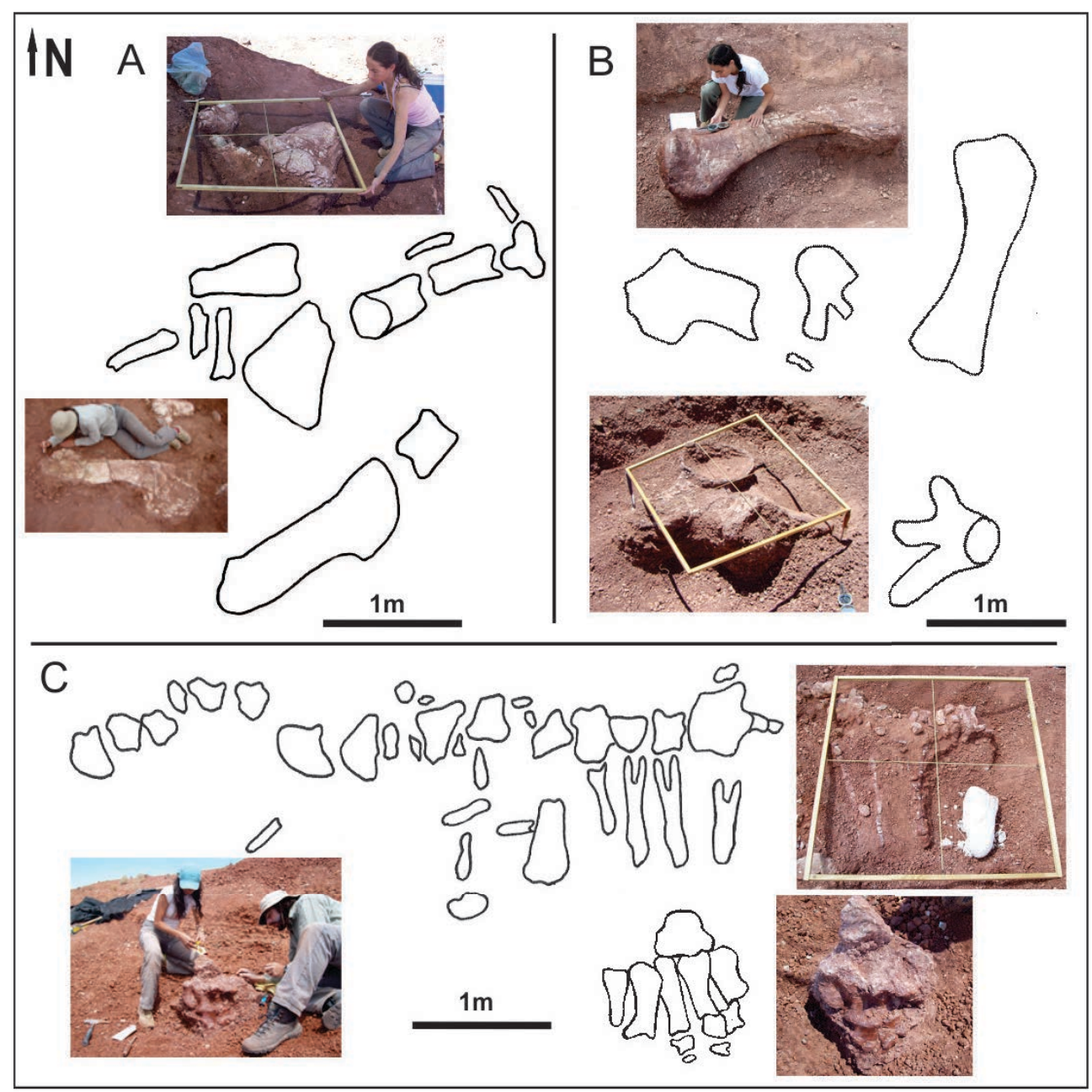

FIG. 7. Quarry maps of Cerro Guillermo (Mendoza, Argentina) showing the spatial distribution of dinosaur remains. A. CG1 site; B. CG2 site; C. CG3 site. See text for further explanation.

concretions adhered to its external surface. These concretions are very abundant in the fossil-bearing floodplain facies and were subjected to intense pedogenetic processes. This type of crusting masks the existence of borings or bioerosion signals that may have affected the remains during the biostratinomic stage.

The distortions observed in the bones occurred during the early diagenetic stages, when skeletal elements were susceptible to be deformed plastically, because they still conserved organic matter. It can be observed a horizontal thrust of the metatarsals I and II in the articulated foot (Fig. 8M, N). This distortion is interpreted as the product of soil compaction by lithostatic load on pelitic facies.

\section{Discussion}

\subsection{Taphonomic modes of vertebrates}

Behrensmeyer and Hook (1992) observed that terrestrial organisms conserved in specific sedimentary contexts show similar fossil preservation patterns. They define these recurring types of preservation as "taphonomic modes" integrating sedimentological and taphonomic data in order to expand the knowledge of each paleontological site. Several taphonomic modes have been recognized by previous authors such as isolated complete skulls of macrovertebrates, complete articulated and disarticulated skeletons, associated partial specimens, large monospecific 


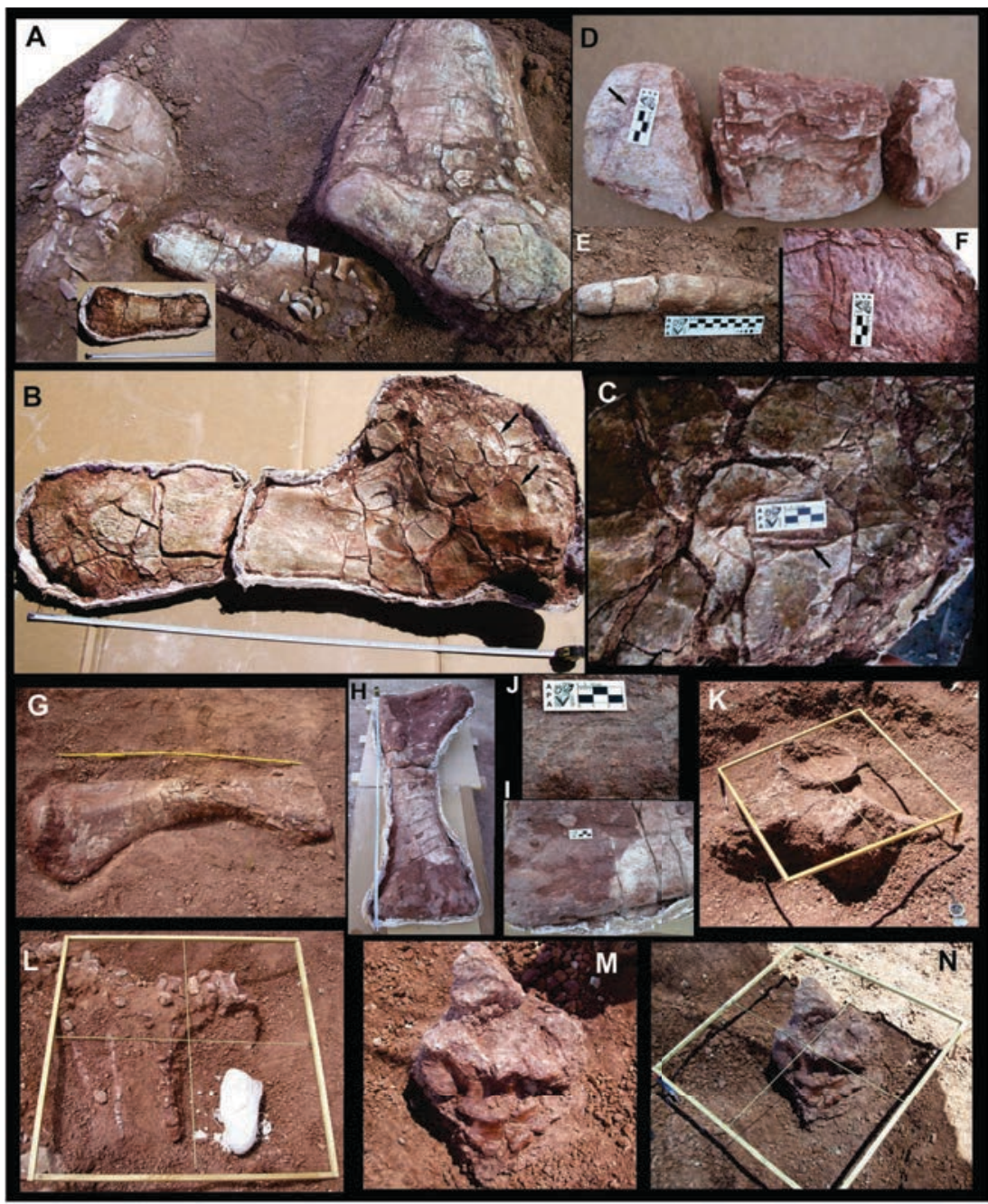

FIG. 8. Taphonomic modifications in dinosaur remains from the Cerro Guillermo area. A-F. Skeletal remains of a sauropod indet. IANIGLA-PV.113 from the CG1 site, FL 2. A. Associated bones (distal end of femur, fibula and proximal end of humerus) showing the longitudinal cracks that suggest advanced weathering; B-F. Appendicular bones, dorsal ribs and the scapula show transverse, oblique fractures and tubular fossil traces on the external surface; G-K. Skeleton remains of Notocolossus gonzalezparejasi UNCUYO-LD. 301 from the CG2 site, FL 1. The right humerus and dorsal vertebra display slight cracking of the periosteum; I, J. The right humerus showing bioerosion attributes on its external surface; L-N. Skeleton remains of Notocolossus gonzalezparejasi UNCUYO-LD. 302 from the CG3 site, FL 1. L.The anterior caudal section shows slight weathering before burial; M, N. The foot displays slightly horizontal thrust of the metatarsals I and II due to compaction phenomena. See text for further explanation.

bonebeds and isolated bones (e.g., Varricchio and Horner, 1993; Varricchio, 1995; Heinrich, 1999; Eberth and Currie, 2005; Csiki et al., 2010; Smith et al., 2015).

The dinosaurs of Cerro Guillermo (CG1, CG2 and CG3 sites) from the Plottier Formation occur in three distinctive taphonomic modes within mudrock and sandstones of the facies associations
(A-B) accumulated on a floodplain, and also complexes of channels, respectively . Most of the dinosaur remains found correspond to sauropods recovered in facies of floodplains. In contrast, the isolated bones of sauropod and theropod transported together through fluvial channels are scarce. Every taphonomic mode reflects the interactions between taphonomic attributes of fossils and the sedimentary 
context prevailing between death and final burial. Each dinosaur taxon was assigned a taphonomic mode modified from those proposed by Eberth and Currie (2005) according to the following criteria: (1) Disarticulated/Articulated (complete or partial), (2) Associated, or (3) Isolated. The taphonomic modes derived from Cerro Guillermo (CG1, CG2 and CG3) assemblages are described below.

\subsubsection{Taphonomic mode 1. Disarticulated-associated bones in well-drained floodplains}

Associated specimens are frequently found and they represent the most common preservation mode in the studied sites. Disarticulated but still associated bones of a sauropod indet. were preserved in the sandy mudstones deposited on the floodplain in the (CG1 site, fossil level (FL 2)). These lithofacies show scarce development of paleosol horizons and the sedimentation rate was slow and essentially episodic.

The bones were found close to the death site, within the same area, disarticulated and somewhat scattered. However, the elements remained in association confirming their parautochthonous condition, such as it was found in other dinosaur sites at Neuquén Group (MT1 from González Riga et al., 2003, 2007). They showed evidence of partial disarticulation, subaerial biodegradation, weathering and cracking. Some bones displayed processes of preferential orientation, hydraulic sorting and sedimentary abrasion. This fact indicates that they were oriented and dispersed by shallow currents during flood episodes of the alluvial plain. Although the bones were reworked by processes of disarticulation and dispersion, they remained within the area of death. On the other hand, the absence of calcareous crusting favored the intense abrasion.

\subsubsection{Taphonomic mode 2. Associated partial skeletons in well-drained floodplains}

Incomplete skeletons usually include associated remains of the axial and appendicular skeleton, ranging from 2 to 3 disarticulated bones to accumulations of partly articulated remains from various body parts (e.g., Smith et al., 2002; Van Itterbeeck et al., 2004; González Riga et al., 2007; Csiki et al., 2010; Smith et al., 2015). This taphonomic mode is registered in the fossil level (FL1) in both CG2 and CG3 sites and comprises two associated partial skeletons assigned to Notocolossus gonzalezparejasi. The dinosaur remains also were preserved in the sandy mudstones deposited on the floodplain facies, but in this case, the lithofacies show a well-developed paleosols. In the dinosaurbearing lithofacies, the processes of bioturbation and pedogenesis were very intense and contributed to the oxidation of sediments and recycling of organic matter. The carbonates and other minerals available in this depositional environment caused the rapid permineralization and partially articulated preservation of the specimens.

The specimen found in the CG2 site was preserved very close to the death site, within the same area, with a short pre-burial phase. Since the bones remained for some time on the surface, they underwent processes of dispersion, subaerial biodegradation, weathering, bioerosion and crusting. The absence of sorting by shape and size in the bones as well as of preferential orientations indicate scarce hydraulic transport processes. In this case, evidences suggest biological intervention (predators and/or scavengers) as dispersing agents. These parautochthonous fossil assemblages resulted from the decay and burial of partially complete carcasses.

The specimen of the CG3 site was preserved at the site of death, without evidence of transport and with a very short pre-burial time period favoring articulated conservation. The absence of skeletal parts, which are easily destroyed and/ or removed, suggests that these skeletons were subjected to short-distance transport, limited and selective dispersal and/or removal of the elements. The most portion of the skeleton it disappeared, possibly result of predatory or scavenging activity, as hydraulic transport seemed an unlikely cause. The skeletal elements do not evidence weathering either intense or slight, abrasion, bioerosion, and orientation produced by sporadic currents. They exhibit a calcareous crusting, calcareous concretions and distortions. The articulated preservation without evidence of weathering together with the sedimentary context suggests the absence of hydraulic action. Based on the available evidence so far, it is considered that biological organisms (predators or scavengers) acted as dispersing agents during the burial history. However, for to confirm this interpretation, further studies are necessary. This mode of occurrence confirms their autochthonous condition. 


\subsubsection{Taphonomic mode 3. Isolated bones in fluvial channels}

Isolated bones represent the less frequent occurrence of dinosaur remains in the Cerro Guillermo area. The saurischian remains (sauropods and theropods) were preserved in the coarse-grained sandstones deposited on the channel floor as "lag deposits" formed under extreme flow conditions (i.e., high-energy and large transport capacity). This taphonomic mode is registered in the (CG2 site, fossil level (FL 2)) and comprise bones preserved away from the site of death. These isolated bones show highly fragmentary nature and are usually weathered and abraded, such as it was found in other taphonomic sites in the Neuquén Group (MT2 of González Riga et al., 2003). They show pre-burial signs like complete disarticulation, weathering, fracturing, abrasion and sorting by hydraulic processes.

Phenomena of sorting and abrasion in skeletal parts, in channel lags and bars, generally indicate some degree of transport and hydraulic selection. Therefore, the bones are considered allochthonous which were transported together by high-energy currents, mixed and reworked. The skeletal remains of different specimens, time intervals and origin areas were preserved together within the same area. This fact confirmed the existence of "time averaging" in these fossiliferous concentrations.

\subsection{Taphonomic pathways}

The genesis of the bone accumulations recognized in the Cretaceous deposits of Cerro Guillermo (CG1, CG2 and CG3 sites) can be explained within a relatively simple scenario. After death, the carcasses were subjected to sequences of biostratinomic processes (vertebrate taphonomy; Table 2) leading to the formation of the above described taphonomic modes. These different taphonomic pathways were dependent on the cause of death; place of death; local depositional environment; climate cycle as well as anatomy and preservational potential of the different organisms (Csiki et al., 2010).

Prior to burial, the sauropod bones found in the floodplain likely undergone processes of prefossilization weathering as temperature changes, solar radiation, saturation and desiccation, all common in environments with episodic sedimentation (Bridge, 2003). The carcasses were sometimes subaerially exposed for long time periods, leading to the almost complete removal of the soft tissue and weathering as well as dispersal and fragmentation of the bones. Biostratinomic processes were favored by the development of sub-arid episodes within the floodplain. These episodes are confirmed by the presence of eolian sandstones at the Cerro Colorado section -Río Neuquén Subgroup- (González Riga, 2002) laterally correlated to the study area. Behrensmeyer (1978) described similar features in bones under arid or saline conditions.

Moreover, the periods of flooding with high sediment input into the floodplain were favourable to concentration and burial of partial carcasses and isolated bones, concentrating the fragmentary remains in fluvial channels. The presence of articulated remains can be explained by transport of the respective skeletal parts into the place of burial as partial carcasses or by rapid in situ burial in still soft sediments deposited on the floodplain. Well-drained floodplain fossil assemblages, especially the common incomplete and partial skeletons are characterized by a higher degree of articulation. On the other hand, parautochthonous burial of partial skeletons in, or very close to, the site of death might have also occurred in these distal floodplain settings, leading to the formation of taphocoenoses dominated by the associated remains of one single individual (Csiki et al., 2010).

In the associated specimens, the taphonomic signatures are more constant suggesting a similar taphonomic history. The sauropod remains were preserved in the sandy mudstones in well-drained floodplains with different degree of paleosols development, from a lesser level of develop as seen in CG1 site, until higher levels as observed in CG2 and CG3 sites. Well-drained bearing floodplains fossils were sites of intense bioturbation and pedogenesis in which organic debris were readily oxidized (Bridge, 2006). This type of environment was optimal for the preservation of organic remains (e.g., root traces, burrows and articulated/disarticulated bones) in the study area.

In contrast, the isolated saurischian bones preserved in the coarse-grained sandstones of the CG2 site, and transported through the fluvial channel-lag formed under extreme flow conditions, experienced complete disarticulation, weathering, fracturing, abrasion and sorting due to hydrodynamic processes. These bones are considered allochthonous because that they were transported together by high-energy currents, mixed and reworked. This type of occurrence showed that taphocoenoses was accumulated and 
reworked during several years because multiple events confirming "time averaging" of remains (sensu Kidwell and Behrensmeyer, 1993). Frequently, advanced weathering and abrasion stages characterize bones preserved in coarse-grained deposits, while these modifications are usually less profound in floodplain deposits.

Furthermore, diagenetic processes, mineralization and compaction, which occurred in the burial environments (floodplain and fluvial channel) has been recognized in a previous study (Previtera, 2017). According to this study, after the burial, the main diagenetic processes that affected the dinosaur bones were compaction, plastic deformation, permineralization and substitution. The ionic substitution of the hydroxyapatite by francolite -in the bone microstructure- was confirmed, in the first moment through the XRD analysis (see Previtera, 2017), and also by the SEM-EDS method performed here. This is a typical mineral replacement of fossilized bone (Lucas and Prévôt, 1991; Kolodny et al., 1996; Elorza et al., 1999) and it is common in many other dinosaur sites (e.g., Hubert et al., 1996; Pereda-Suberbiola et al., 2000; Paik et al., 2001; Luque et al., 2009; Rogers et al., 2010; Piga et al., 2011; among others).

Especially, the existence of "open fractures" in saurischian bones indicates post-fossilization weathering processes -subaerial exposure- flaking and fracturing occurred during exhumation events (telodiagenesis). These processes are the result of the differences in burial depth, temperature and geostatic pressure suffered by the fossils in each burial environment (Previtera, 2017). Similar fossil-diagenetic features have been identified in other cretaceous tetrapod assemblages of Patagonia (González Riga and Astini, 2007; González Riga et al., 2009; Casal et al., 2013; Previtera, 2011, 2013).

Changes in the preservation of fluvial transported fossils over time has been influenced not only by evolution of life on land but also by changes in climate and tectonic activity. Variations in these latter cause modifications also in the depositional environments and hence in the types of organisms present and their modes of preservation. Some important stages in the evolution of life on land relating to fossil preservation are given in previous investigations (e.g., Behrensmeyer and Hook, 1992; Buatois et al., 1998; Driese et al., 2000; Shear and Selden, 2001).

In summary, the most of the dinosaur remains analized here come from facies of distal floodplains of meandering fluvial systems, in contrast to the observed in other localities of Mendoza as Arroyo Seco (González Riga, 2003; González Riga and Astini, 2007), and northern Patagonia such as Rincón de los Sauces (Calvo and González Riga, 2003) in which the dinosaur remains come mostly from overbank facies of these systems.

\section{Conclusions}

The study of the CG1, CG2 and CG3 fossiliferous sites from the Plottier Formation allowed the recognition of different taphonomic modes within these deposits, from isolated bones to partially articulated skeletons of dinosaurs preserved in meandering fluvial systems. The distribution of the different taphonomic modes within sedimentary facies in Cerro Guillermo is uneven. Isolated bones commonly occurred in channel deposits, whereas associated partial skeletons were dominantly found in distal floodplain deposits (especially well-drained ones). Although the composition of these modes might seem unexpected in the light of previous studies, their genesis can be explained as result of taphonomic processes that operated within a fluvial environment under a semi-arid climate, seasonally variable, linked to periods of water deficit. This multidisciplinary survey represents an interesting local taphonomic pattern about saurischian dinosaurs preservation in different burial environments during the Upper Cretaceous.

\section{Acknowledgments}

This paper evolved from discussions of taphonomic and environmental aspects of the author's doctoral dissertation at the Universidad Nacional de Córdoba, Argentina. I would like to thank especially B. González Riga (Thesis Director) for his direction and advice in the geological and paleontological studies that made this manuscript possible and R. Astini (Thesis Co-director) for his important contribution in sedimentary analysis. The IANIGLA-CCT-Mendoza provided assistance during field and laboratory work (electron microscope). SEM and EDS analysis were provided by MEBYM (IANIGLACONICET). I gratefully acknowledge both anonymous reviewers for their constructive and valuable comments which improved the manuscript. I thank very much M. Bourguet and C. Sancho for their valuable support in the fieldworks. I am particularly grateful to A. Mancuso for her constructive comments and L. Starkman for improving 
the English version. This research was supported by the following projects: PICT BID 2005/33984 to J. Calvo, PIP CONICET 5222 to W. Volkheimer, and PIP 0713/09 to B. González Riga.

\section{References}

Alcalá Martínez, L. 1994. Macromamíferos neógenos de la fosa de Alfambra-Teruel. Departamento de Paleontología de la Facultad de Ciencias Geológicas de la Universidad Complutense de Madrid. Instituto de Estudios Turolenses y Museo de Ciencias Naturales: 554 p. Teruel.

Andreis, R.R.; Iñíguez Rodríguez, A.M.; Lluch, J.J.; Sabio, D.A. 1974. Estudio sedimentológico de las formaciones del Cretácico Superior del área del Lago Pellegrini, Provincia de Río Negro, República Argentina. Revista de la Asociación Geológica Argentina 29: 85-104.

Andrews, P. 1990. Owls, caves and fossils. The Natural History Museum: 231 p. London.

Bastin, G.F.; Van Loo, F.J.J.; Heijligers, H.J.M. 1986. Evaluation of the use of Gaussian $\varphi(\rho z)$ curves in quantitative electron probe microanalysis: A new optimization. X-Ray Spectrometry 13: 91-97.

Behrensmeyer, A.K. 1978. Taphonomic and ecologic information from bone weathering. Paleobiology 4: 150-162.

Behrensmeyer, A.K. 1991. Terrestrial vertebrate Accumulations. In Topics in Geology (Allison, P.A.; Briggs, D.E.G.; editors). Plenum Press: 291-327. Nueva York.

Behrensmeyer, A.K.; Hook, R.W. 1992. Paleoenvironmental contexts and taphonomic modes. In Terrestrial ecosystems through time: evolutionary paleoecology of terrestrial plants and animals (Behrensmeyer, A.K.; Damuth, J.D.; DiMichele, W.A.; Potts, R.; Sues, H.D.; Wing, S.L.; editors). University of Chicago Press: 15-136. Chicago.

Bonaparte, J.F. 1991. The Gondwanan theropod families Abelisauridae and Noasauridae. Historical Biology 5: $1-25$.

Bridge, J.S. 1993. Descriptive and interpretation of fluvial deposits: a critical perspective. Sedimentology 40: 801-810.

Bridge, J.S. 2003. Rivers and floodplains. Blackwell Publishing: 608 p. Oxford.

Bridge, J.S. 2006. Fluvial facies models: recent developments. In Facies Models revisted (Crossey, L.J.; McNeill, D.S.; editors). SEPM Society for Sedimentary Research, Special Publication 84: 85-170. Tulsa.

Britt, B.B.; Eberth, D.A.; Scheetz, R.; Greenhalgh, B. 2004. Taphonomy of the DaltonWells dinosaur quarry (Cedar
Mountain Formation, Lower Cretaceous, Utah). Journal of Vertebrate Paleontology, Abstract 24 (3): $41 \mathrm{~A}$.

Britt, B.B.; Eberth, D.A.; Scheetz, R.D.; Greenhalgh, B.W.; Stadtman, K.L. 2009. Taphonomy of debrisflow hosted dinosaur bonebeds at Dalton Wells, Utah (Lower Cretaceous, Cedar Mountain Formation, USA). Palaeogeography, Palaeoclimatology, Palaeoecology 280: 1-22.

Brown, C.M.; Evans, D.C.; Campione, N.E.; O’Brien, L.J.; Eberth, D.A. 2013. Evidence for taphonomic size bias in the Dinosaur Park Formation (Campanian, Alberta), a model Mesozoic terrestrial alluvial-paralic system. Palaeogeography, Palaeoclimatology, Palaeoecology 372: 108-122.

Buatois, L.A.; Mangano, M.G. 1995. Paleoenvironmental and paleoecological significance of the lacustrine Mermia ichnofacies: and archetypical subaqueous non-marine trace fossil assemblage. Ichnos 4: 151-161.

Buatois, L.A.; Mangano, M.G. 1996. Icnología de ambientes continentales: problemas y perspectivas. Asociación Paleontológica Argentina, Publicación Especial 4: 5-30.

Buatois, L.A.; Mangano, M.G.; Genise, J.F.; Taylor, T.N. 1998. The ichnologic record of the continental invertebrate invasion: evolutionary trends in environmental expansion, ecospace utilization, and behavioral complexity. Palaios 13: 217-240.

Calvo, J.O.; González Riga, B.J. 2003. Rinconsaurus caudamirus gen. et sp. nov., a new titanosaurid (Dinosauria, Sauropoda) from the Late Cretaceous of Patagonia, Argentina. Revista Geológica de Chile 30: 333-353. doi: 10.5027/andgeoV30n2-a11.

Calvo, J.O.; Porfiri, J.D.; Veralli, C.; Novas, F.E.; Poblete, F. 2004. Phylogenetic status of Megaraptor namunhuaiquii Novas based on a new specimen from Neuquén, Patagonia, Argentina. Ameghiniana 41: 565-575.

Calvo, J.O.; Porfiri, J.D.; González Riga, B.J.; Kellner, A. 2007. A new Cretaceous terrestrial ecosystem from Gondwana with the description of a new sauropod dinosaur. Anais da Academia Brasileira de Ciencias 79: 529-541.

Canudo, J.I.; Oms, O.; Vila, B.; Galobart, A.; Fondevilla, V.; Puertolas-Pascual, E.; Selles, A.C.; CruzadoCaballero, P.; Dinares-Turelle, J.; Vicens, E.; Castanera, D.; Company, J.; Burrel, L.; Estrada, R.; Marmi, J.; Blanco, A. 2016. The upper Maastrichtian dinosaur fossil record from the southern Pyrenees and its contribution to the topic of the Cretaceouse Palaeogene mass extinction event. Cretaceous Research 57: 540-551. 
Casal, G.A.; Martínez, R.D.; Ibiricu L.M.; González Riga, B.; Foix, N. 2013. Tafonomía del dinosaurio terópodo Aniksosaurus darwini, Formación Bajo Barreal, Cretácico Tardío de Patagonia, Argentina. Ameghiniana 50: 571-592.

Casal, G.A.; Ibiricu, L.M.; Allard, J.O.; Martínez, R.D.; Luna, M.; González Riga, B. 2014. Tafonomía del titanosaurio Aeolosaurus colhuehuapensis, Cretácico Superior, Patagonia central, Argentina: un ejemplo de preservación en facies continentales fluviales. Revista Mexicana de Ciencias Geológicas 31: 163-173.

Cazau, L.B.; Uliana, M.A. 1973. El Cretácico Superior continental de la cuenca Neuquina. In Congreso Geológico Argentino, No. 5, Actas III: 131-163. Buenos Aires.

Chiappe, L.M.; Schmitt, J.G.; Jackson, F.D.; Garrido, A.; Dingus, L.; Grellet-Tinner, G. 2004. Nest Structure for Sauropods: Sedimentary Criteria for Recognition of Dinosaur Nesting Traces. Palaios 19: 89-95.

Cohen, K.M.; Finney, S.C.; Gibbard, P.L.; Fan, J. 2013. The ICS International Chronostratigraphic Chart. Episodes 36 (3): 199-204.

Coria, R.A.; Currie, P.J. 2006. A new carcharodontosaurid (Dinosauria, Theropoda) from the Upper Cretaceous of Argentina. Geodiversitas 28: 71-118.

Csiki, Z.; Grigorescu, D.; Codrea, V.; Therrien, F. 2010. Taphonomic modes in the Maastrichtian continental deposits of the Haţeg Basin, Romania-Palaeoecological and palaeobiological inferences. Palaeogeography, Palaeoclimatology, Palaeoecology 293: 375-390.

Curry Rogers, K. 2005. Titanosauria. In The Sauropods, evolution and paleobiology (Curry Rogers, K.A.; Wilson, J.A.; editors). University of California Press: 50-103. Berkeley.

Dai, H.; Xing, L.; Marty, D.; Zhang, J.; Persons, W.S.; Hu, H.; Wang, F. 2015. Microbially-induced sedimentary wrinkle structures and possible impact of microbial mats for the enhanced preservation of dinosaur tracks from the Lower Cretaceous Jiaguan Formation near Qijiang (Chongqing, China). Cretaceous Research 53: 98-109.

De Ferraríis, C. 1968. El Cretácico del norte de la Patagonia. In Jornadas Geológicas Argentinas, No. 3, Actas I: 121-144. Buenos Aires.

Digregorio, J.H.; Uliana, M.A. 1980. Cuenca Neuquina. In Geología Regional Argentina (Turner, J.C.M.; editor). Academia Nacional de Ciencias 2: 985-1032. Córdoba.

Dingus, L.; Garrido, A.C.; Scott, G.R.; Chiappe, L.M.; Clarke, J.; Schmitt, J.G. 2009. The litho-, bio-, and magnetostratigraphy of titanosaurian nesting sites in the Anacleto Formation at Auca Mahuevo (Campanian, Neuquén Province, Argentina). In Papers on Geology, Vertebrate Paleontology and Biostratigraphy in Honor of Michael O. Woodburne (Albright, L.B.; editor). Museum of Northern Arizona, Bulletin 65: 237-258. Arizona.

Donovan, S.K.; Paul, C.R.C. 1998. The adequacy of the fossil record. John Wiley and Sons: 312 p. New York.

Driese, S.G.; Mora, C.I.; Elick, J.M. 2000. The paleosol record of increasing plant diversity and depth of rooting and changes in atmospheric $\mathrm{pCO}_{2}$ in the SiluroDevonian. In Phanerozoic Terrestrial Ecosystems, A Short Course: New Haven, Connecticut (Gastaldo, R.A.; DiMichele, W.A.; editors). The Paleontological Society 6: 47-61.

Eberth, D.A.; Currie, P.J. 2005. Vertebrate taphonomy and taphonomic modes. In Dinosaur Provincial Park: A Spectacular Ancient Ecosystem Revealed: Life of the Past (Currie, P.J.; Koppelhus, E.B.; editors). Indiana University Press: 453-477. Bloomington.

Eberth, D.A.; Currie, P.J. 2010. Stratigraphy, sedimentology and taphonomy of the Albertosaurus bonebed (Upper Horseshoe Canyon Formation; Maastrichtian), southern Alberta, Canada. Canadian Journal of Earth Sciences 47: 1119-1143.

Eberth, D.A.; Britt, B.B.; Scheetz, R.; Stadtman, K.L.; Brinkman, D.B. 2006. Dalton Wells: geology and significance of debris-flow-hosted dinosaur bonebeds in the Cedar Mountain Formation (Lower Cretaceous) of eastern Utah, USA. Palaeogeography, Palaeoclimatology, Palaeoecology 236: 217-245.

Ekdale, A.A.; Bromley, R.G.; Pemberton, S.G. 1984. Ichnology, Trace Fossils. In Sedimentology and Stratigraphy. Society of Economic Palaeontologists and Mineralogists (SEPM), Short Course 15: 317 p. Tulsa.

Elorza, J.; Astibia, H.; Murelaga, X.; Pereda-Suberbiola, X. 1999. Francolite as a diageneticmineral in dinosaur and other Upper Cretaceous reptile bones (Laño, Iberian Peninsula): microstructural, petrological and geochemical features. Cretaceous Research 20: 169-187.

Fisher, S.G.; Heffernan, J.B.; Sponseller, R.A.; Welter, J.R. 2007. Functional ecomorphology: Feedbacks between form and function in fluvial landscape ecosystems. Geomorphology 89: 84-96.

Franzese, J.; Spalletti, L.; Gómez Pérez, J.; Macdonald, D. 2003. Tectonic and paleoenvironmental evolution of Mesozoic sedimentary basins along Andean foothills of Argentina ( $32^{\circ}-54^{\circ} \mathrm{S}$ ). Journal of South American Earth Sciences 16: 81-90. 
Frey, R.W.; Pemberton, S.G.; Fagerstom, J.A. 1984. Morphological, ethological and environmental significance of the ichnogenera Scoyenia and Ancorichnus. Journal of Paleontology 58: 511-528.

Friend, P.F. 1983. Towards the field classification of alluvial architecture or sequence. In Modern and Ancient Fluvial System (Collinson, J.D.; Lewin, J.; editors). International Association of Sedimentologists, Special Publication 6: 345-354.

Friend, P.F.; Slater, M.J.; Williams, R.C. 1979. Vertical and lateral building of river sandstone bodies, Ebro Basin, Spain. Journal of the Geological Society of London 136: 39-46.

Garrido, A.C. 2010. Estratigrafía del Grupo Neuquén, Cretácico Superior de la Cuenca Neuquina (Argentina): nueva propuesta de ordenamiento litoestratigráfico. Revista del Museo Argentino de Ciencias Naturales 12 (2): 121-177. Buenos Aires.

Garrido, A.C.; Chiappe, L.M.; Jackson, F.; Schmitt, J.; Dingus, L. 2001. First sauropod nest structures. Journal of Vertebrate Paleontology 21 (3): 53A.

Google Earth Pro. Mendoza, Argentina date image: october 1, 2006, 3706'48.15'S, 69²3'05.60"W, elevation $863 \mathrm{~m}$, eye alt $19.92 \mathrm{~km}$. Image 2016 Digitalglobe http: //www.earth.google.com.

González Riga, B.J. 2002. Estratigrafía y Dinosaurios del Cretácico Tardío en el extremo sur de la provincia de Mendoza, Argentina. Ph.D. Thesis (Unpublished), Universidad Nacional de Córdoba: 280 p. Argentina.

González Riga, B.J. 2003. A new titanosaur (Dinosauria, Sauropoda) from the Upper Cretaceous of Mendoza Province, Argentina. Ameghiniana 40: 155-172.

González Riga, B.J.; Astini, R.A. 2007. Preservation of large titanosaur sauropods in overbank fluvial facies: A case study in the Cretaceous of Argentina. Journal of South American Earth Sciences 23: 290-303.

González Riga, B.J.; Ortiz David, L. 2014. A new titanosaur (Dinosauria, Sauropoda) from the Upper Cretaceous (Cerro Lisandro Formation) of Mendoza Province, Argentina. Ameghiniana 51: 3-25.

González Riga, B.J.; Calvo, J.O.; Previtera, E. 2007. Análisis tafonómicos de saurópodos titanosaurios en la Cuenca Neuquina (Argentina) y sus implicancias en estudios sistemáticos. In Colectivo Arqueológico y Paleontológico de Salas de los Infantes. Jornadas Internacionales sobre Paleontología de Dinosaurios y su entorno, Actas: 235-241. Burgos.

González Riga, B.J.; Calvo, J.O.; Porfiri, J. 2008. An articulated titanosaur from Patagonia (Argentina): new evidences of the pedal evolution. Palaeoworld 17: 33-40.
González Riga, B.J.; Previtera, E.; Pirrone, C.A. 2009. Malarguesaurus florenciae gen. et sp. nov., a new titanosauriform (Dinosauria, Sauropoda) from the Upper Cretaceous of Mendoza, Argentina. Cretaceous Research 30: 135-148.

González Riga, B.J.; Calvo, J.O.; Astini, R.A.; Parras, A.M. 2003. Preservación tafonómica de titanosaurios (Dinosauria, Sauropoda) en facies fluviales del sector septentrional de la Cuenca Neuquina. Ameghiniana 40 (4): 102R.

González Riga, B.J.; Lamanna, M.C.; Ortiz David, L.D.; Calvo, J.O.; Coria, J.P. 2016. A gigantic new dinosaur from Argentina and the evolution of the sauropod hind foot. Scientific Reports 6: 1-15.

González Riga, B.J.; Mannion, P.D.; Poropat, S.F.; Ortiz David, L.D.; Coria, J.P. 2018. Osteology of the Late Cretaceous Argentinean sauropod dinosaur Mendozasaurus neguyelap: implications for basal titanosaur relationships. Zoological Journal of the Linnean Society 20: 1-46.

Groeber, P. 1946. Observaciones geológicas a lo largo del meridiano $70^{\circ} .1$, Hoja Chos Malal. Revista de la Sociedad Geológica Argentina 1 (3): 177-208.

Heer, O. 1877. Flora Fossils Helvetidae. Die vorweltliche Flora der Schweiz. J. Würster and Co.:182 p. Zurich.

Heinrich, W.D. 1999. The taphonomy of dinosaurs from the Upper Jurassic of Tendaguru (Tanzania) based on field sketches of the German Tendaguru Expedition (1909-1913). Mitteilungen Museum fur Naturkunde Berlin, Geowissenschaftliche Reihe 2: 25-61.

Howell, J.A.; Schwarz, E.; Spalletti, L.A.; Veiga, G.D. 2005. The Neuquén Basin: an overview. In The Neuquén Basin, Argentina: A Case Study in Sequence Stratigraphy and Basin Dynamics (Veiga, G.; Spalletti, L.; Howell, J.; Schwarz, E.; editors). Geological Society of London, Special Publications 252 (1): 1-14.

Hubert, J.F.; Panish, P.T.; Chure, D.J.; Prostak, K.S. 1996. Chemistry, micro-structure, petrology, and diagenetic model of Jurassic dinosaur bones, Dinosaur National Monument, Utah. Journal of Sedimentary Research 66: 531-547.

Hugo, C.A.; Leanza, H.A. 2001. Hoja geológica 3969-IV General Roca (escala 1:250.000) Provincias de Río Negro y Neuquén. Instituto de Geología y Recursos Minerales. Servicio Geológico Minero Argentino (SEGEMAR), Boletín 308: 1-65. Buenos Aires.

Keidel, J. 1917. Über das patagonische Tafelland undihre ziehungen zu den geologischen ercheinnugen in den Argentinischen Anden gebiet und Litoral. Zeitschrift der Deutsche Akademie Wiessenschaft 3: 219-245. 
Kidwell, S.M.; Behrensmeyer, A.K. 1993. Summary: estimates of time-averaging. In Taphonomic Approaches to Time Resolution in Fossil Assemblages (Kidwell, S.M.; Behrensmeyer, A.K.; editors). Short Courses in Paleontology, No. 6. Paleontological Society: 301-302. Knoxville, Tennesee.

Kolodny, Y.; Luz, B.; Sander, M.; Clemens, W.A. 1996. Dinosaur bones: fossils or pseudomorphs? The pitfalls of physiology reconstruction from apatitic fossils. Palaeogeography, Palaeoclimatology, Palaeoecology 126: $161-171$.

Leanza, H.A. 2009. Las principales discordancias del Mesozoico de la Cuenca Neuquina según observaciones de superficie. Revista del Museo Argentino de Ciencias Naturales, Nueva Serie 11: 145-184. Buenos Aires.

Leanza, H.A.; Hugo, C.A. 2001. Cretaceous red beds from southern Neuquén Basin, Argentina: age, distribution and stratigraphic discontinuities. In Asociación Paleontológica Argentina (Leanza, H.A.; editor). International Simposium on Mesozoic Terrestrial Ecosystem, No. 7, Publicación Especial 7: 117-122. Buenos Aires.

Leanza, H.A.; Apesteguia, S.; Novas, F.; De La Fuente, M.S. 2004. Cretaceous terrestrial beds from the Neuquén Basin, Argentina and their tetrapod assemblages. Cretaceous Research 25: 61-87.

Legarreta, L.; Gulisano, C.A. 1989. Análisis estratigráfico secuencial de la Cuenca Neuquina (Triásico superiorTerciario inferior). In Cuencas Sedimentarias Argentinas (Chebli, G.; Spalletti, L.; editores). Facultad de Ciencias Naturales, Universidad Nacional de Tucumán, Serie Correlación Geológica 6: 221-243. San Miguel de Tucumán.

Legarreta, L.; Uliana, M.A. 1991. Jurassic-Cretaceous marine oscillations and geometry of back-arc basin fill, central Argentine Andes. In Sedimentation, Tectonics and Eustasy: Sea level Changes at Active Plate Margins (MacDonald, D.I.; editor). International Association of Sedimentologists, Special Publication 12: 429-450. Oxford.

Legarreta, L.; Kokogian, D.A.; Boggetti, D.A. 1989. Depositional sequences of de Malargüe Group (Upper Cretaceous-Lower Tertiary), Neuquén Basin, Argentina. Cretaceous Research 10: 337-356.

Lucas, J.; Prévôt, L.E. 1991. Phosphates and Fossil Preservation. In Taphonomy: Releasing the Data Locked in the Fossil Record (Allison, P.A.; Briggs, D.E.G.; editors). Plenum Press: 389-409. New York.

Luque, L.; Alcalá, L.; Mampel, L.; Pesquero, M.D.; RoyoTorres, R.; Cobos, A.; Espílez, A.G.; Ayala, D. 2009.
Mineralogical, Elemental and Chemical Composition of Dinosaur Bones from Teruel (Spain). Journal of Taphonomy 7: 151-178.

Lyman, R.L. 1994. Vertebrate Taphonomy. Cambridge University Press: $524 \mathrm{p}$.

Marshall, L.G. 1989. Bone modification and "the laws of burial". In Bone modification (Bonnichsen, R.; Sorg, M.H.; editors). University of Maine Center for the Study of the First Americans 7-24. Orono.

Martinsen, O.J.; Ryseth, A.; Helland-Hansen, W.; Flesche, H.; Torkildsen, G.; Idil, S. 1999. Stratigraphic base level and fluvial architecture: Ericson Sandstone (Campanian), Rock Springs Uplift, SW Wyoming, U.S.A. Sedimentology 46: 235-259.

Méndez, V.; Zanettini, J.C.; Zappetini, E.O. 1987. Aspectos geológicos del Orógeno Andino Central de la República Argentina. In Congreso Geológico Argentino, No. 8, Actas I: 181-184. Tucumán.

Miall, A.D. 1985. Architectural-element analysis: a new method of facies analysis applied to fluvial deposits. Earth Science Review 22: 261-308.

Miall, A.D. 1996. The Geology of Fluvial Deposits. Springer-Verlag Berlin Heidelberg: 583 p. New York.

Novas, F.E. 1996. Alvarezsauridae, Cretaceous basal birds from Patagonia and Mongolia. Memoirs of the Queensland Museum 39: 675-702.

Novas, F.E. 1997. Megaraptor namunhuaiquii, gen. et sp. nov., a large clawed Late Cretaceous theropod from Patagonia. Journal of Vertebrate Paleontology 18: 4-9.

Novas, F.E.; Puerta, P. 1997. New evidence concerning avian origins from the Late Cretaceous of Patagonia. Nature 387: 390-392.

Paik, I.S.; Kim, H.J.; Park, K.H.; Song, Y.S.; Lee, Y.I.; Hwang, J.Y.; Huh, M. 2001. Paleoenvironments and taphonomic preservation of dinosaur bone-bearing deposits in the Lower Cretaceous Hasandong Formation, Korea. Cretaceous Research 22: 627-642.

Pereda-Suberbiola, X.; Astibia, H.; Murelaga, X.; Elorza, J.J.; Gómez-Alday, J.J. 2000. Taphonomy of the Late Cretaceous dinosaur-bearing beds of the Laño Quarry (Iberian Peninsula). Palaeogeography, Palaeoclimatology, Palaeoecology 157: 247-275.

Piga, G.; Santos-Cubedo, A.; Brunetti, A.; Piccinini, M.; Malgosa, A.; Napolitano, E.; Enzo, E. 2011. A multi-technique approach by XRD, XRF, FT-IR to characterize the diagenesis of dinosaur bones from Spain. Palaeogeography, Palaeoclimatology, Palaeoecology 310: 92-107.

Plint, A.G.; Browne, G.H. 1994. Tectonic event stratigraphy in a fluvio-lacustrine, strike-slip setting: the Boss Point 
Formation (Westphalian A), Cumberland Basin, Maritime Canada. Journal Sedimentary Research 64: 341-364.

Powell, J.E. 2003. Revision of South American Titanosaurid dinosaurs: palaeobiological, palaeobiogeographical and phylogenetic aspects. Records of the Queen Victoria Museum: 173 p. Launceston.

Previtera, E. 2011. Tafonomía de Dinosaurios Cretácicos de la Cuenca Neuquina sur mendocina, Patagonia Argentina. Ph.D. Thesis (Unpublished), Universidad Nacional de Córdoba: 202 p.

Previtera, E. 2013. Tafonomía de vertebrados del Cretácico Superior de la Formación Loncoche en Calmuco (Mendoza, Argentina): implicancias paleoambientales y paleogeográficas. Ameghiniana 50: 483-492.

Previtera, E. 2017. Bone microstructure and diagenesis of saurischian dinosaurs from the Upper Cretaceous (Neuquén Group), Argentina. Andean Geology 44 (1): 39-58. doi: 10.5027/andgeoV44n1-a03.

Ramos, V. 1981. Descripción geológica de la Hoja 33c, Los Chihuidos Norte, Provincia de Neuquén. Servicio Geológico Nacional, Boletín 182: 1-103. Buenos Aires.

Retallack, G.J. 2001. Soils of the Past. An introduction to Paleopedology. Blackwell Science: 404 p. Oxford.

Rogers, R.R.; Eberth, D.A.; Fiorillo, A.R. 2007. Bonebeds: Genesis, analysis, and paleobiological significance. The University of Chicago Press: 499 p. Chicago.

Rogers, R.R.; Fricke, H.C.; Addona, V.; Canavan, R.R.; Dwyer, C.N.; Harwood, C.L.; Koenig, A.E.; Murray, R.; Thole, J.T.; Williams, J. 2010. Using laser ablationinductively coupled plasma-mass spectrometry (LA-ICP-MS) to explore geochemical taphonomy of vertebrate fossils in the Upper Cretaceous Two Medicine and Judith River formations of Montana. Palaios 25: 183-195.

Salgado, L.; Coria, R.A.; Calvo, J.O. 1997. Evolution of Titanosaurid Sauropods. I: Phylogenetic analysis based on the postcraneal evidence. Ameghiniana 34: 3-32.

Sánchez, M.L.; Heredia, S.; Calvo, J.O. 2006. Paleoambientes sedimentarios del Cretácico Superior de la Formación Plottier (Grupo Neuquén), departamento de Confluencia, Neuquén. Revista de la Asociación Geológica Argentina 64: 3-18.

Schwarz, E. 2012. Sharp-based marine sandstone bodies in the Mulichinco Formation (Lower Cretaceous), Neuquén Basin, Argentina: remnants of transgressive offshore sand ridges. Sedimentology 59: 1478-1508.

Shear, W.A.; Selden, P. A. 2001. Rustling in the undergrowth: animals in early terrestrial ecosystems. In Plants Invade the Land (Gensel, P.G.; Edwards, D.; editors). Columbia University Press: 29-51. New York.

Smith, R.M. 1993. Vertebrate Taphonomy of Late Permian floodplain deposits in the Southwestern Karoo Basin of South Africa. Palaios 8: 45-67.

Smith, R.M.H.; Sidor, C.A.; Tabor, N.J.; Steyer, J.S. 2015. Sedimentology and vertebrate taphonomy of the Moradi Formation of northern Niger: A Permian wet desert in the tropics of Pangaea. Palaeo-geography, Palaeoclimatology, Palaeoecology 440: 128-141.

Smith, T.; Codrea, V.; Săsăran, E.; Van Itterbeeck, J.; Bultynck, P.; Csiki, Z.; Dica, P.; Fărcaş, C.; Folie, A.; Garcia, G.; Godefroit, P. 2002. A new exceptional vertebrate site from the Late Cretaceous of the Haţeg Basin (Romania). Studia Universitatis Babes-Bolyai. Geologia, Special Issue 1: 321-330.

Tunik, M.; Folguera, A.; Naipauer, M.; Pimentel, M.; Ramos, V. 2010. Early uplift and orogenic deformation in the Neuquén Basin: Constraints on the Andean uplift from $\mathrm{U}-\mathrm{Pb}$ and $\mathrm{Hf}$ isotopic data of detrital zircons. Tectonophysics 489: 258-273.

Van Itterbeeck, J.; Săsăran, E.; Codrea, V.; Săsăran, L.; Bultynck, P. 2004. Sedimentology of the Upper Cretaceous mammal-and dinosaur-bearing sites along the Râul Mare and Bărbat rivers, Haţeg Basin, Romania. Cretaceous Research 25: 517-530.

Varricchio, D.J. 1995. Taphonomy of Jack's Birthday Site, a diverse dinosaur bonebed from the Upper Cretaceous Two Medicine Formation of Montana. Palaeogeography, Palaeoclimatology, Palaeoecology 114: 297-323.

Varricchio, D.J.; Horner, J.R. 1993. Hadrosaurid and lambeosaurid bone beds from the Upper Cretaceous Two Medicine Formation of Montana: taphonomic and biologic implications. Canadian Journal of Earth Sciences 30: 997-1006.

Vergani, G.D.; Tankard, A.J.; Belotti, H.J.; Weisink, H.J. 1995. Tectonic evolution and paleogeography of the Neuquén Basin, Argentina. In Petroleum Basins of South America, American Association of Petroleum Geologists, Memoir 62: 383-402.

Wilson, J.A. 2002. Sauropod dinosaur phylogeny: critique and cladistic analysis. Zoological Journal of the Linnean Society 136: 217-276.

White, P.D.; Fastovsky, D.E.; Sheehan, P.M. 1998. Taphonomy and suggested structure of the dinosaurian assemblage of the Hell Creek Formation (Maastrichtian), eastern Montana and western North Dakota. Palaios 13: 41-51.

Manuscript received: January 6, 2018; revised/accepted: September 07, 2018; available online: February 04, 2019. 